\title{
Species richness of lichen functional groups in relation to land use intensity
}

\author{
Silvia STOFER, Ariel BERGAMINI, Gregorio ARAgón, Palmira CARVALHO, \\ Brian J. COPPINS, Simon DAVEY, Michael DIETRICH, Edit FARKAS, \\ Kati KÄRKKÄINEN, Christine KELLER, László LÖKÖS, Sampsa LOMMI, \\ Cristina MÁGUAS, Ruth MITCHELL, Pedro PINHO, Víctor J. RICO, \\ Anne-Marie TRUSCOTT, Patricia A. WOLSELEY, Allan WATT and \\ Christoph SCHEIDEGGER
}

\begin{abstract}
Changing land use has a major impact on lichen diversity. This study attempts to identify patterns or trends of lichen functional groups along a land use gradient, ranging from natural forests to open agricultural landscape. In eight countries, covering six main European biogeographic regions, lichen vegetation was assessed according to a standardized scheme. Data on reproductive, vegetative and ecological traits was compiled and relative species richness for all classes of all traits calculated. Relationships between the land use gradient and relative species richness of trait classes were analysed. Open and intensively managed landscapes harbour more fertile species while sterile species are relatively more important in forests. This finding is also supported by analyses of different classes of dispersal propagules. The importance of species with the principal photobiont Trebouxia s.l. increases linearly with intensification of land use. A converse pattern is revealed by species with Trentepohlia. Concerning substratum specialization only generalists show an effect along the land use intensity gradient. Their relative species richness decreases from landscapes dominated by forests to open agricultural landscape. A considerable decline in the rare lichen species richness as a result of land intensification is predicted.
\end{abstract}

Key words: Europe, functional groups, land use intensity, lichen diversity

S. Stofer, A. Bergamini, C. Keller and C. Scheidegger: Swiss Federal Research Institute WSL, Zürcherstr. 111, CH-8903 Birmensdorf, Switzerland.

G. Aragón: Área de Biodiversidad y Conservatión, ESCET, Universidad Rey Juan Carlos, c/Tulipán s.n., 28933 Móstoles (Madrid), Spain.

P. Carvalho: Museu Nacional de História Natural, Jardim Botanico, Rua da Escola Politécnica, 58, 1250102 Lisboa, Portugal.

B. J. Coppins: Royal Botanic Garden Edinburgh, Inverleith Row, Edinburgh, EH3 5LR, United Kingdom S. Davey: Stable Flat, Downsland Court, 115 East End Lane, Ditchling, Hassocks, Sussex, BN6 8UR, United Kingdom or Dept. of Zoology, University College Dublin, Belfield, Dublin 4, Ireland.

M. Dietrich: I de Böde, CH-6010 Kriens, Switzerland. E. Farkas: Institute of Ecology and Botany, Hungarian Academy of Sciences, H-2163 Vacratot, Hungary.

K. Kärkkäinen: Department of Ecology and Systematics, P.O. Box 65, 00014 University of Helsinki, Finland.

\section{Introduction}

Several studies have shown that the influence of human activities on biodiversity is unprecedented as natural habitats have been

L. Lökös: Department of Botany, Hungarian Natural History Museum, H-1476 Budapest, Pf. 222, Hungary. S. Lommi: The Finnish Forest Research Institute, Vantaa Research Centre, Vantaa Unit, PL 18, 01301 Vantaa, Finland.

C. Máguas and P. Pinho: FCUL, Centro de Ecologia e Biologia Vegetal, Depto. de Biologia Vegetal, Bloco 2C, Campo Grande, 1749-016, Lisboa, Portugal.

R. Mitchell, A.-M. Truscott and A. Watt: Centre for Ecology and Hydrology (CEH), Banchory, Hill of Brathens, Banchory, Aberdeenshire, AB31 4BW, Scotland, United Kingdom.

V. J. Rico: Departamento de Biología Vegetal II, Facultad de Farmacia, Universidad Complutense, E-28040 Madrid, Spain.

P. A. Wolseley: Department of Botany, The Natural History Museum, Cromwell Road, London SW7 5BD, United Kingdom. 
displaced by human disturbance on at least $50 \%$ of the global land surface (Hannah et al. 1994; Sanderson et al. 2002; Turner II 2002), and it is predicted that land use change and habitat conversion will continue in future (Sala et al. 2000; Tilman et al. 2001). In Europe only 15.6\% of the land surface remained undisturbed (Hannah et al. 1994), largely restricted to the most unproductive regions. Changes in land use have a strong influence on species diversity and species composition (Rosenzweig 1995; Hacker \& Gaines 1997; Turner et al. 2001) which in turn clearly depend on the pool of species of the regions studied. Thus, studying effects of environmental variables on species composition reveals no generalizable insights because of the limited geographical distribution of most species. Although lichen species have a larger distribution area than, for example, vascular plants, lichen floras of different biogeographic regions within Europe show considerable differences (Bergamini et al. 2005). Therefore, a better strategy for understanding and predicting effects of land use changes on lichen vegetation may be to study effects on the distribution of functional traits rather than effects on the distribution of species.

In comparison to better known groups such as vascular plants (Diaz et al. 2004), we still know very little about functional traits in lichens and their response to various impacts such as land use, disturbance or climate change. There has been little effort so far to build functional classifications of lichens or to fit them into existing schemes (Rogers 1990; During 1992; Jahns \& Ott 1997; Wolseley 1997), mainly because relevant information on important traits such as competitive ability or relative growth rate are not readily available. The relevance of functional classifications may depend further on environmental conditions, for example traits sensitive to land use change or disturbance may be quite different to those sensitive to climate change. There may also be some regional dependence of the importance of some traits (Diaz et al. 2002), reducing the usefulness of general classifications. For example a species may be a good competitor in one region, but a bad one in other regions.

In this paper we explore whether there are patterns or trends in the relative importance of various lichen traits along a land use gradient. The land use gradient was replicated in eight European countries and ranged from closed natural forests to open agricultural landscapes (A. Watt, personal communication). Previous work (Bergamini et al. 2005) showed that this land use gradient had significant effects on lichen species richness and composition. We collected a diverse range of data from various literature resources on different ecological, vegetative and reproductive lichen traits for which a functional relationship to land use was hypothesized.

\section{Methods}

\section{Study area and sampling design}

This study is part of the EU-funded project BioAssess which aims to develop biodiversity indicators across land use gradients in Europe. Fieldwork was performed in eight countries and six main biogeographic regions of Europe (Alpine, Switzerland; Atlantic, Ireland and United Kingdom; Boreal, Finland; Continental, France; Mediterranean, Portugal and Spain; Pannonic, lowlands of the Danube river plain in Hungary, characterized by warm and dry summers and cold winters). In each country one study region was selected. Within each study region six $1 \mathrm{~km}^{2}$ land use units (LUUs) were chosen, one in each of the following land use classes: old-growth, more or less unmanaged forest (LUU1); managed, mainly secondary forest (LUU2); woodland dominated landscape (LUU3); mixed-use landscape (LUU4); pasture dominated landscape (LUU5); farmland (LUU6). In each LUU lichen vegetation was assessed according to a complex scheme (for details see Scheidegger et al. 2002). In brief, we established in each LUU a regular grid (mesh size $200 \mathrm{~m}$ ) resulting in 16 intersections. Each intersection was the centre of a circular sampling plot of 1 ha $(56.4 \mathrm{~m}$ radius). Within each sampling plot twelve randomly selected collecting sites served as the starting point for three lichen relevés (total area of $50 \times 40 \mathrm{~cm}$ each), one on each of the following substrata: rocks, bark of living trees, and "other" (including soil, bryophytes, small pebbles, dead wood, shrubs, and saplings ). All lichenized fungi with a minimum size of $5 \mathrm{~mm}$, except parasites were considered. When species could not be identified in the field, specimens were collected for further identification in the laboratory (microscopy and thin-layer chromatography). Keys listed in Nimis \& Martellos (2004) 
TABLE 1. Reproductive, vegetative and ecological traits recorded for each lichen species

Trait Description

\section{Reproductive traits \\ 1. Fertility \\ 2. Propagules}

3. Spore length and shape

4. Spore septation

\section{Vegetative traits}

5. Growth form

6. Photobiont

Ecological traits

7. Substratum specialization

8. Rarity
Two classes: 1 : mostly sterile; 2 : mostly fertile (regularly producing ascospores).

Five classes of lichen propagules and their combinations: 1: symbiotic propagules (soredia and/or isidia); 2 : soredia; 3 : isidia; 4: fungal propagules (ascospores and/or conidia); 5: conidia; small thallus fragments were considered as isidia.

Four classes (combination of two spore length and two spore shape classes): 1: short and globose to ellipsoid; 2: short and elongate; 3: long and globose to ellipsoid; 4: long and elongate.

Definition of two spore length classes: short spores $(\leq 15 \mu \mathrm{m})$ and long spores $(>15 \mu \mathrm{m})$. Two spore shape classes were defined by the ratio of average spore length/average spore width: globose to ellipsoid spores (ratio $\leq 2.5$ ) and elongate spores (ratio $>2.5$ ). Shape terminology modified from Kirk et al. (2001). Species of the class 'mostly fertile' from trait 1 were considered only.

Four classes: 1: no septum; 2: 1-septate; 3: 3-septate or more; 4: muriform. Species of the class 'mostly fertile' from trait 1 were considered only.

Five classes modified from Büdel \& Scheidegger (1996): 1: crustose; 2: foliose-adpressed; 3: foliose ascendant; 4: fruticose-erect; 5 : fruticose-pendulous.

Three classes: 1: green algae (excluding Trentepohlia); 2: Trentepohlia; 3: Nostoc. In tripartite lichens only the green algal photobiont was considered.

Three classes: 1: specialist (restricted to one substratum); 2: intermediate type (growing on two or three different substrata); 3: generalist (growing on more than three substrata). Rock, soil, living trees, deadwood and bryophytes were considered as possible substrata.

Three classes modified from Rabinowitz (1981): 1: wide distribution and high abundance in most areas; 2 : wide distribution and high abundance in some areas, but rare in others; 3: narrow distribution, high or low abundance. Reference area was Europe. were used for species identification. Specimens were deposited in the following herbaria: $\mathrm{BM}, \mathrm{BP}, \mathrm{H}, \mathrm{MAF}$, DBN, LISU (abbreviations after Holmgren et al. 1990) and at the Federal Research Institute WSL. Field work was carried out in 2001 and 2002. Different groups of co-authors of this study were responsible for sampling and determination in their country.

\section{Species traits}

We compiled data on reproductive, vegetative and ecological traits for each of the 768 lichen species found in the study (Table 1). A multitude of literature was used to assemble the data. The most important data sources were Purvis et al. (1992), Clauzade \& Roux (1985), Poelt (1969), Poelt \& Vězda (1977, 1981) and (Wirth 1995). Determinations for the trait 'fertility' and the trait 'rarity' were based on expert opinion. See Appendix for the complete species list with assigned trait values for each species.

\section{Data analysis}

For each class of each trait (Table 1) relative species richness (called 'relative richness' in the following for convenience) was calculated as follows: first the species number of all classes of a certain trait for each of the 48 LUUs were summed. Then the species numbers of each class of that trait was divided by this sum. This provided relative richness for that trait class in that LUU. One LUU6, farmland of Portugal, was excluded from all analyses of relative richness because no lichens at all were found in this LUU and therefore no relative richness could be calculated. Changes in relative richness along the land use gradient for a certain trait class reflect the changing dominance of groups of species exhibiting that trait class. However, one has to be aware that the changing dominance measured in that way is always in terms of species richness and not abundance.

Analysis of variance (ANOVA) was used to study the relationships between the land use gradient and relative 
richness of trait classes. In all the analyses, countries were included as blocking factor. In a first series of ANOVAs, the land use gradient was considered as a fixed factor with six levels. If the overall effect of the land use gradient was at least marginally significant $(P \leq 0 \cdot 1)$, we used Tukey's HSD procedure for pair wise comparisons of means of relative richness between levels of the land use gradient. In a second series of ANOVAs the land use gradient as an ordered factor was considered. For these ANOVAs LUU2 (managed forest) was omitted. We performed the same analyses as in the first series, but now we tested for linear trends of the land use gradient on relative richness. By this procedure, it was possible to detect significant trends in the data which were not detected by pair wise comparisons. In all ANOVAS homogeneity of variances was checked graphically by Tukey-Anscombe plots, and normality of the residual distribution by normal probability plots. If variances were not homogeneous and/or residuals not normally distributed, we used the arcsine transformation for relative richness which considerably improved residual distributions in these cases. This is the standard transformation used for proportions (Sokal \& Rohlf 1995). Despite this transformation, outlying values in some analyses were problematic. To cope with these LUUs, we constructed for each outlier a new variable with only two values: 1 for the outlying LUU, zero for all other LUUs. If there were problems with an outlying LUU, we included the respective variable as an additional covariable into the ANOVA. Transformations used and covariables included are indicated in Table 2. All analyses revealed that LUU2 of Portugal (Eucalyptus-forest) was very different from all other LUUs and was therefore excluded from the analyses.

Because many univariate ANOVAS were performed, the probability of reporting significant results just by chance was increased. Therefore, results with $P$ values $>0.01$ should be interpreted with caution.

All analyses were carried out with R 2.3.0 (R Development Core Team 2006).

\section{Results}

For all species groups defined on the various trait classes we found highly significant block (= country) effects. This remained true even if we considered block effects as random and not fixed, because a possible treatment (=LUU) $\times$ block interaction would only increase the residual mean squares and the treatment mean squares but not the block mean squares; i.e. F-values for blocks are either correct or too low (Sokal \& Rohlf 1995; Hulbert 2004).

For all species, we found a significant overall effect of land use $\left(\mathrm{F}_{5,34}=2 \cdot 75\right.$, $P=0.034)$ on lichen species richness and a significant linear trend with decreasing species richness along the gradient. Differences in means, however, were only significant between extremes of land use - LUU1 and LUU6 (Bergamini et al. 2005). The relationships between the land use gradient and relative richness of trait classes as revealed by analyses of variance are summarized in Table 2 . In the following paragraphs we concentrate on significant effects of land use units on relative richness of the trait-defined groups. Where results of pair wise comparisons were significant, figures showing means of the land use units are presented.

\section{Reproductive traits}

Relative richness of mostly sterile species exhibited a clear pattern. It decreased linearly along the gradient (Table 2). Pair wise comparisons revealed that LUU6 (farmland) in particular had a lower mean (Fig. 1A). A similar pattern was revealed looking at the different classes of symbiotic propagules. Relative richness of species capable of producing symbiotic propagules, soredia only or isidia only was significantly lower in LUU6 (farmland). Furthermore, relative richness of these trait classes decreased linearly from LUU1 to LUU6 (Table 2; Fig. 1B-D).

In contrast, relative richness of fertile species increased linearly along the land use gradient. Pair wise comparisons revealed that LUU6 (farmland) in particular had a higher mean (Fig. 1E). The same pattern was revealed by species producing fungal propagules (Fig. 1F). Relative richness of conidia producing species, however, was indifferent to the gradient (Table 2).

Relative richness of species with short and globose to ellipsoid spores increased along the gradient (Table 2). Species with long spores, on the other hand, were relatively more important in forests as revealed by the pair wise comparisons and the linear contrasts (Table 2, Fig. 1D \& H). The number of species with unicellular or with 1-septate spores remained more or less constant across the gradient (Table 2). Relative richness of species with 2- or more septate spores 
TABLE 2. Effects of the land-use gradient on relative richness of trait classes as revealed by ANOVA

\begin{tabular}{|c|c|c|c|c|c|c|}
\hline Traits & Trait class & Transformation $\dagger$ & Covariables $\ddagger$ & $F$ & Trend $\Omega$ & $\begin{array}{l}\text { Sign of } \\
\text { trend } \$\end{array}$ \\
\hline \multicolumn{7}{|l|}{ Reproductive traits } \\
\hline \multirow[t]{2}{*}{ Fertility } & Mostly sterile & $-1-$ & $-1-$ & $6 \cdot 46^{\star \star \star}$ & $\star \star \star$ & - \\
\hline & Mostly fertile & $-1-$ & $-1-$ & $7 \cdot 58^{\star \star \star}$ & $\star \star \star$ & + \\
\hline \multirow[t]{5}{*}{ Propagules } & Symbiotic prop. & $-/ a \sin$ & $-1-$ & $5 \cdot 75^{\star \star \star}$ & $\star \star \star$ & - \\
\hline & Soredia & $\operatorname{asin} /-$ & $-1-$ & $3 \cdot 61^{\star}$ & $\star \star$ & - \\
\hline & Isidia & $\operatorname{asin} / a \sin$ & -/Ire 6 & $2 \cdot 92^{\star}$ & $\star \star \star$ & - \\
\hline & Fungal prop. & $-/-$ & Hun5/Hun5 & $8 \cdot 09^{\star \star \star}$ & $\star \star \star \star$ & + \\
\hline & Conidia & $-/$ asin & $-1-$ & $0 \cdot 49$ & & \\
\hline \multirow[t]{4}{*}{ Spore length \& shape } & Short \& glob./ellip. & $-1-$ & Hun5/Hun5 & $3 \cdot 72^{\star \star}$ & $\star \star$ & + \\
\hline & Long \& glob./ellip. & $-1-$ & Hun6/Hun6 & $4 \cdot 01^{\star \star}$ & $\star$ & - \\
\hline & Short \& elongate & $-/-$ & $-1-$ & $0 \cdot 59$ & & \\
\hline & Long \& elongate & asin/asin & Hun4/- & $4 \cdot 23^{\star \star}$ & $\star \star$ & - \\
\hline \multirow[t]{4}{*}{ Spore septation } & No septation & $-/-$ & $-1-$ & $1 \cdot 29$ & & \\
\hline & 1-septate & $-/-$ & $-1-$ & $1 \cdot 72$ & & \\
\hline & 3 -septate or more & $\operatorname{asin} / a \sin$ & $-1-$ & $3 \cdot 04^{\star}$ & $\star$ & - \\
\hline & muriform & asin/asin & Ire2/Ire6 & $1 \cdot 95$ & $\star \star$ & - \\
\hline \multicolumn{7}{|l|}{ Vegetative traits } \\
\hline \multirow[t]{5}{*}{ Growth form } & Crustose & $-1-$ & Hun5/Hun5 & $1 \cdot 19$ & & \\
\hline & Fol.-adpressed & $-1-$ & Hun5/Hun5 & $11 \cdot 00^{\star \star \star}$ & $\star \star \star$ & + \\
\hline & Fol.-ascendant & $-1-$ & Hun5/Hun5 & $1 \cdot 71$ & & \\
\hline & Frut.-erect & $-1-$ & $-1-$ & $4 \cdot 10^{\star \star}$ & $\star \star \star$ & - \\
\hline & Frut.-pend. & $-/ a \sin$ & $-1-$ & $1 \cdot 42$ & & \\
\hline \multirow[t]{4}{*}{ Photobiont } & Green algae & & & & & \\
\hline & (excl. Trentepohlia) & $\operatorname{asin} / \operatorname{asin}$ & $-1-$ & $2 \cdot 44^{\star \star}$ & $\star \star$ & + \\
\hline & Trentepohlia & $\operatorname{asin} / \operatorname{asin}$ & $-1-$ & $2 \cdot 86^{\star}$ & $\star \star$ & - \\
\hline & Nostoc & asin/asin & Spa1/Spa1 & $1 \cdot 52$ & & \\
\hline \multicolumn{7}{|l|}{ Ecological traits } \\
\hline \multirow[t]{3}{*}{ Substratum specialization } & Specialists & $-1-$ & Hun5/- & $2 \cdot 16$ & & \\
\hline & Intermediates & $-1-$ & $-1-$ & $0 \cdot 39$ & & \\
\hline & Generalists & $-/ a \sin$ & Hun6/Hun6 & $6 \cdot 22^{\star \star \star}$ & $\star \star \star$ & - \\
\hline \multirow[t]{3}{*}{ Rarity } & Wide, abundant & asin/asin & Hun5/Hun5 & $7 \cdot 13^{\star \star \star}$ & $\star \star \star$ & + \\
\hline & Wide, partly rare & $\operatorname{asin} /-$ & Hun5/Hun5 & $6 \cdot 72^{\star \star \star}$ & $\star \star \star$ & - \\
\hline & Narrow & asin/asin & $-1-$ & $3 \cdot 01^{\star}$ & $\star \star$ & - \\
\hline
\end{tabular}

†Transformations of relative richness and additional covariables are indicated for the ANOVAs of the first series before the slash, and for the ANOVAs of the second series (trend analyses) after the slash; asin: arcsine.

‡Ire2: Ireland LUU2 Ire6: Ireland LUU6, Hun5: Hungary LUU5, Hun6: Hungary LUU6, Spa1: Spain LUU1, ${ }^{\star} P \leq 0 \cdot 05,{ }^{\star \star} P \leq 0 \cdot 01,{ }^{\star \star \star} P \leq 0 \cdot 001$.

§Significance and sign of trends of the second ANOVA series. Residual degrees of freedom for ANOVAs of the first series are usually 33, and for the second series are usually 27 . If a covariable is included, these values are reduced by one.

significantly decreased along the gradient (Table 2).

\section{Vegetative traits}

Only three classes of the trait growth form revealed linear trends along the land use gradient. While relative richness of folioseadpressed lichens increased along the gradient, fruticose-erect species decreased in importance from LUU1 to LUU6 (Table 2). Results of pair wise comparisons between means of relative richness of folioseadpressed and fruticose-erect lichens are shown in Fig. 2A and B.

The importance of species with green algae (excl. Trentepohlia) as the principal photobiont increased linearly along the 

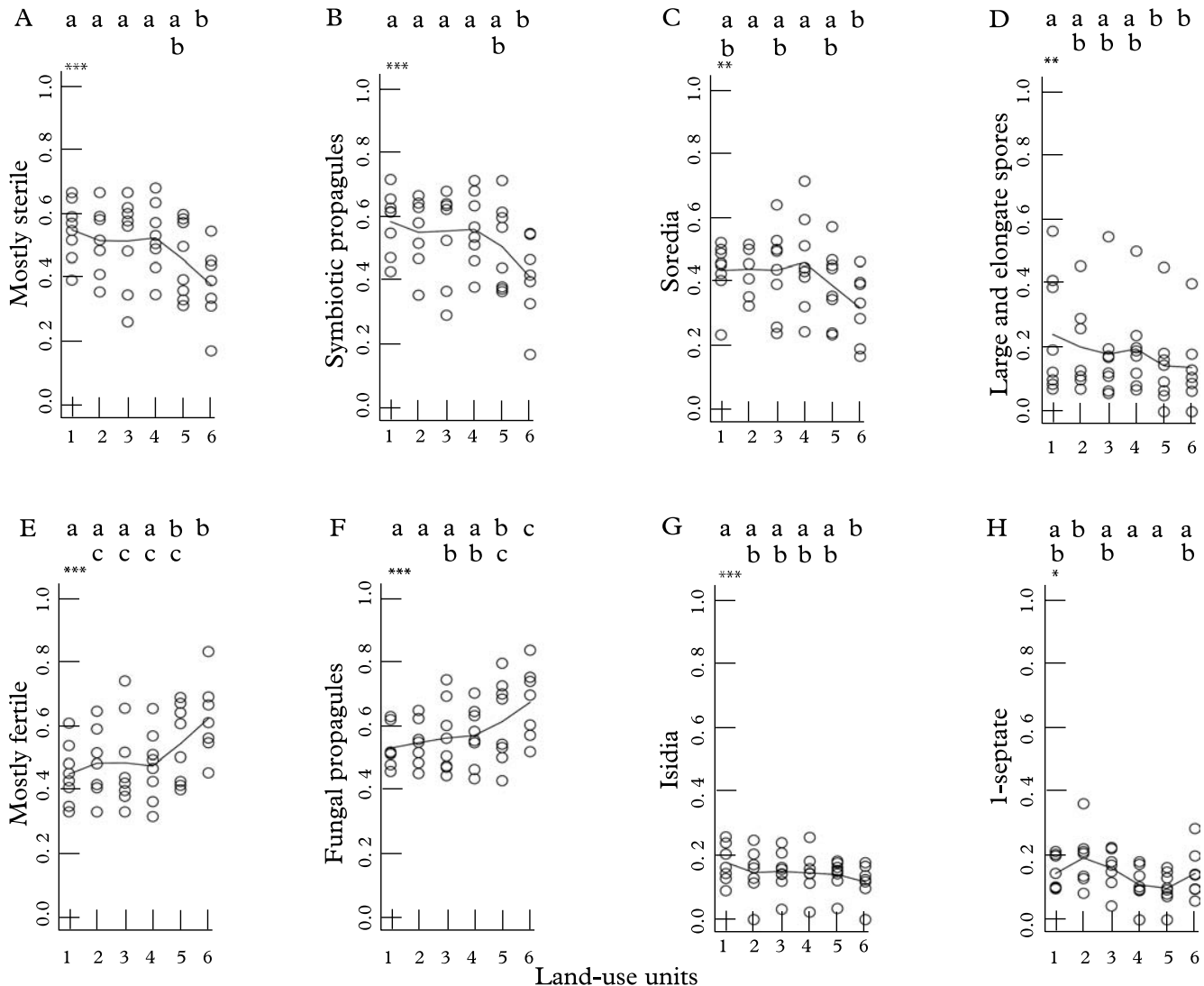

Fig. 1. Effects of land use units on relative richness of classes defined by fertility (A \& E), propagules (B, C, F \& G), spore length $\&$ shape $(\mathrm{D} \& \mathrm{H})$. See Table 1 for details of classes. Mean relative richness values with the same letter (top $x$-axis) are not significantly different at the $P \leq 0.05$ level as revealed by pair wise comparisons (Tukey HSD). Lines connect means for land use units. Significance of trends is indicated by stars in the upper left corner of each diagram $\left({ }^{\star} P \leq 0 \cdot 05,{ }^{\star} \times P \leq 0 \cdot 01,{ }^{\star \star \star} P \leq 0 \cdot 001\right)$. Note that for the calculation of trends LUU2 was omitted. Land use unit 1: old-growth forest, 2 : secondary forest, 3 : mixed-use landscape, dominated by forest, 4 : mixed-use landscape with an equal share of forest and open land, 5: pasture, 6: farmland.

gradient while the importance of species with Trentepohlia decreased linearly (Table 2; Fig. 2C \& D). Contrary to expectations, the land use units had no effects on relative richness of species with Nostoc (Table 2).

\section{Ecological traits}

Considering substratum specialization, only the substratum generalists showed a significant overall effect of the land use units on their relative richness. Moreover, only the generalists exhibited a clear trend along the gradient (Fig. 2E; Table 2). Interestingly, their relative richness decreased from forests (LUU1 and LUU2) to the open farmland.

Overall effects of land use units on relative richness of all three rarity classes were significant. Widespread, abundant species increased in importance from the old-growth forest to the farmland while widespread, but in some areas rare species decreased (Table 2). While relative richness of the former increased from around $40 \%$ to $57 \%$, that of the latter decreased from $53 \%$ to $39 \%$ (Fig. 2F \& G). Relative richness of narrowly distributed species, which may be rare or abundant in their distribution area, also showed a linear decrease from the 

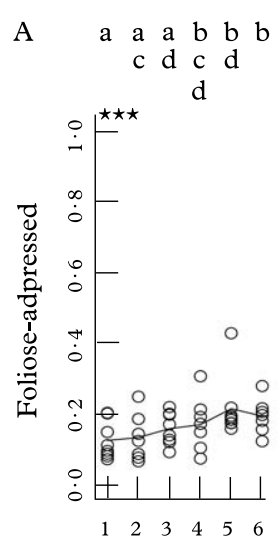

$\mathrm{E}$

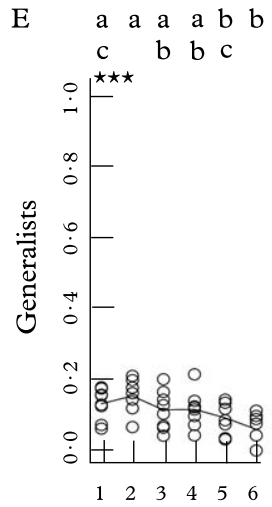

B
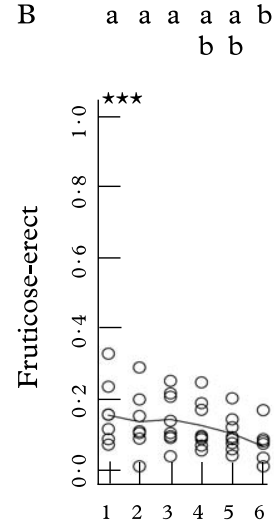

F a a a a b b

c b c c

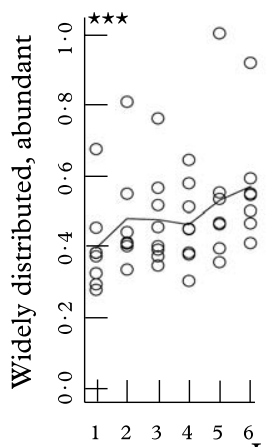

C

a a a a a a

D

a $\quad$ a $\underset{b}{a} \quad \begin{array}{ccc}a & a & b\end{array}$

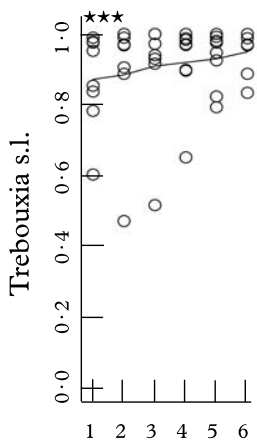

G

a a a $a$ a b

b

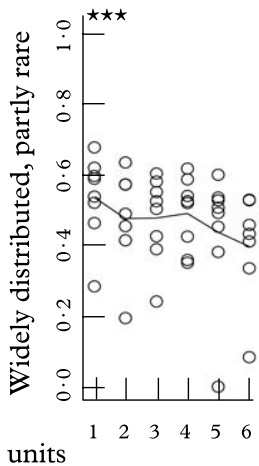

$\mathrm{H}$

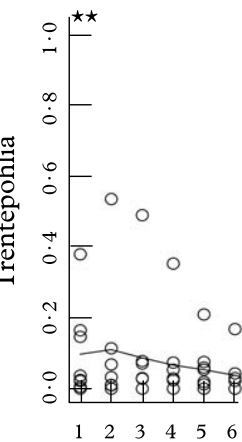

a $a$ a $a b$ b $b$ b b

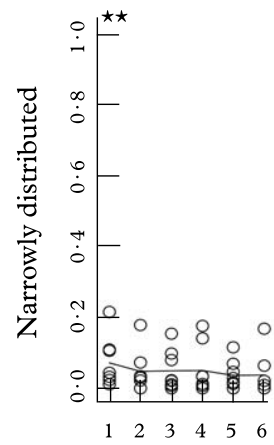

FIG. 2. Effects of land use units on relative richness of classes defined by growth form (A \& B), photobiont (C \& D), substratum specialization $(\mathrm{E})$ and rarity $(\mathrm{F}-\mathrm{H})$. See Table 1 and legend for Fig. 1 for further details.

old-growth forest (LUU1) to the farmland (LUU6; Fig. 2H).

\section{Discussion}

We found significant relationships between many of the reproductive, vegetative and ecological traits considered and land useintensity. This was to some extend expected since land use intensity has a clear effect on lichen species composition (Bergamini et al. 2005). Furthermore, the considered land use gradient was rather broad ranging from natural or semi-natural forests to intensively used agricultural landscapes. Lack of basic knowledge of physiological, reproductive and ecological aspects of many lichen species prevented the compilation of data for many preferable traits such as growth rate, generation length and so on. Nevertheless, our analyses give a valuable basis for the selection of traits for building contextspecific functional classifications.

\section{Reproductive traits}

The results show that species which usually produce fungal propagules, were more often found in open and more intensively managed land use units while forests or landscapes with a high proportion of forest cover harboured more species with 
vegetative symbiotic propagules. Moreover, fertile lichens with multiseptate and long spores appeared more frequently in forested landscapes, independently of spore shape.

There are some fundamental differences between fungal propagules and symbiotic propagules of lichens. Fungal propagules are usually much smaller than symbiotic propagules and they are self-liberating as well as self-transporting over small distances (excluding those of the Caliciales). After dispersal they have to find favourable conditions for germination, and at a later stage a compatible photobiont to establish a new symbiotic phenotype. On the other hand, symbiotic diaspores are usually larger than fungal propagules, they are dispersed by passive means only, but they disseminate the whole lichen symbiosis (Bailey 1976; Lawrey 1984; Tibell 1994). These differences are likely to have consequences on dispersal and establishment. For example, dispersal by wind is influenced by size, shape and volume of the propagules (Tibell 1994; Bjelland 2001). Soredia are likely to be carried farther than isidia but not as far as spores (Pyatt 1973). It is thus suggested that species with small propagules are better adapted to long distance dispersal between suitable habitats whereas species with larger (mostly asexual) propagules are adapted to short-distance dispersal. This is also confirmed by Hedenås \& Ericson (2000) who found sexually dispersed species appearing earlier in successional forests than asexually dispersed species. Furthermore, Walser (2004) found evidence of very limited dispersal of symbiotic propagules in Lobaria pulmonaria by means of molecular analyses. In the non-forested land use units, where suitable localities are more isolated, it may thus be advantageous for lichens to exhibit a sexual reproductive strategy with small spores. Higher establishment capacity of asexual compared to sexual propagules might be advantageous within forests, where establishment rather than dispersal might be limiting as suggested by Hedenås et al. (2003) and Werth et al. (2006).

\section{Vegetative traits}

As expected, land use intensity had pronounced effects on relative richness of the different growth forms. Bergamini et al. (2005) demonstrated that land use intensity affected species richness and density of crustose lichens.

Our studies revealed that with increasing land use intensity the importance of green algae (excl. Trentepohlia) as lichen photobiont increased while it decreased for Trentepohlia. In contrast, we found no effects of land use intensity on lichens with Nostoc as primary photobiont. Little is known about lichen ecology with respect to photobionts except for cyanolichens. Several studies describe a pronounced association of epiphytic cyanolichens with old growth forests (Rose 1976; Gauslaa 1985; Kuusinen 1996; Sillett \& McCune 1998; Goward \& Arsenault 2000). Moreover, cyanolichens play an important role in calcareous rock communities. Therefore, any effects of oldgrowth forests in our study may have been obscured by occurrences of cyanolichens growing on calcareous rocks in any other land use unit along the intensity gradient. In fact, saxicolous cyanolichens were much more evenly distributed over the different land use units than epiphytic cyanolichens (results not shown). Epiphytic cyanolichens were found in only seven of the 48 land use units and just four times in old growth forests. Not every old-growth forest in Europe may be a suitable habitat for cyanolichens. Other factors such as climatic conditions, species composition of forest trees, and insolation of the forest stand may affect occurrence of cyanolichens in forest ecosystems (Hedenås \& Ericson 2000).

\section{Ecological traits}

We found a linear decrease of substratum generalists from the forested land use units to the agricultural landscapes. There may be a close relationship between this pattern and the decrease of sorediate and/or isidiate species along the same gradient. Bowler \& Rundel (1975) found some evidence that sorediate species have broader ecological 
amplitudes than closely related species that disperse by sexual spores only. They argued that asexual propagules can germinate in a broader habitat range since they do not have to re-build the symbiosis. Additional support for this hypothesis comes from Hedenås et al. (2003) who found that a very high proportion of species which occur on a wide range of trees are asexually dispersed.

Rabinowitz (1981) constructed flexible categories of rarities taking into consideration geographic range, habitat specificity and local population size of a species. Only species with a large geographic range, wide habitat specificity and dominant local populations were not defined as rare. Our results showed that widespread, abundant species were more likely to occur with increasing land use intensity, while relative richness of widespread, but in some areas rare species and species showing a narrow distribution decreased. They predict a considerable decline of many rare species if there is a further intensification of already extensively used landscapes.

\section{Limitations}

There are some limitations for the interpretation of our results, which should be kept in mind. First, all the relationships we found are of a correlative nature and are by no means a proof of a functional relationship. The adaptive value of the traits studied with respect to the land use gradient can only be assumed. It might well be that several of the traits studied are correlated with other traits, for example physiological traits such as drought tolerance, which are directly under a selection pressure.

A second point concerns the dependence of data points. Lichen species have been treated as independent data points, however, the predominance of a trait in a certain land use unit may occur for reasons other than its functional or adaptive value. The relative importance of a trait may result from groups of closely related species sharing this trait. This might cause spurious correlations between land use intensity and relative importance of traits.
Finally, we used only species presence/ absence data, i.e. abundance measures were not considered. Therefore, importance of traits is always measured as relative richness of species sharing a certain trait. It does not mean that species with a dominant trait in a certain land use unit are also the dominant species.

We thank the public and private owners of the sites for their co-operation in allowing the study to be carried out on their land. We also thank the following persons involved in the BioAssess project for stimulating discussions: T. Bolger, D. Chamberlain, A. Esteban, R. Fuller, F. Fernández-González, P. Gurrea Sanz, I. Hepburn, E. Ivits, Z. Korsós, B. Koch, P. Lavelle, J. Niemelä, F. Rego, J. P. Sousa, and C. van Swaay. Furthermore we are grateful to U. Groner for fieldwork and E. Meduna various other help. The authors also thank the referees for critical comments on the manuscript. This study was part of the European Community program BioAssess and was supported by the European Union (EVK2-1999-00280) and the Swiss Federal Office for Education and Science (EVK2-CT-199900280, BBW Nr. 99.0683). The first and second author acknowledge funding from the Swiss Federal Office for Education and Science (LACOPE: EVK2-CT-200200150, BBW Nr. 01.0476-1).

\section{REFERENCES}

Bailey, R. H. (1976) Ecological aspects of dispersal and establishment in lichens. In Lichenology: Progress and Problems (D. H. Brown, D. L. Hawksworth \& R. H. Bailey, eds): 215-247. London: Academic Press.

Bergamini, A., Scheidegger, C., Stofer, S., Carvalho, P., Davey, S., Dietrich, M., Dubs, F., Farkas, E., Groner, U., Kärkkäinen, K., Keller, C., Lökös, L., Lommi, S., Máguas, C., Mitchell, R., Pinho, P., Rico, V. J., Aragón, G., Truscott, A.-M., Wolseley, P. A. \& Watt, A. (2005) Performance of macrolichens and lichen genera as indicators of lichen species richness and composition. Conservation Biology 19: 1051-1062.

Bjelland, T. (2001) Comparative studies of the distribution and ecology of some oceanic species in the genus Leptogium (Lecanorales, Ascomycotina) in Norway. Nova Hedwigia 72: 1-44.

Bowler, P. A. \& Rundel, P. W. (1975) Reproductive strategies in lichens. Botanical fournal of the Linnean Society 70: 325-340.

Büdel, B. \& Scheidegger, C. (1996) Thallus morphology and anatomy. In Lichen biology ( $\mathrm{T}$. H. Nash III, ed.): 37-64. Cambridge: Cambridge University Press.

Clauzade, G. \& Roux, C. (1985) Likenoj de Okcidenta Europo. Ilustrita Determinlibro. Royan.

Diaz, S., Hodgson, J. G., Thompson, K., Cabido, M., Cornelissen, J. H. C., Jalili, A., Montserrat-Marti, 
G., Grime, J. P., Zarrinkamar, F., Asri, Y., Band, S. R., Basconcelo, S., Castro-Diez, P., Funes, G., Hamzehee, B., Khoshnevi, M., PerezHarguindeguy, N., Perez-Rontome, M. C., Shirvany, F. A., Vendramini, F., Yazdani, S., Abbas-Azimi, R., Bogaard, A., Boustani, S., Charles, M., Dehghan, M., de Torres-Espuny, L., Falczuk, V., Guerrero-Campo, J., Hynd, A., Jones, G., Kowsary, E., Kazemi-Saeed, F., MaestroMartinez, M., Romo-Diez, A., Shaw, S., Siavash, B., Villar-Salvador, P. \& Zak, M. R. (2004) The plant traits that drive ecosystems: evidence from three continents. Fournal of Vegetation Science 15: 295-304.

Diaz, S., McIntyre, S., Lavorel, S. \& Pausas, J. G. (2002) Does hairiness matter in Harare? Resolving controversy in global comparisons of plant trait responses to ecosystem disturbance. New Phytologist 154: 7-9.

During, H. J. (1992) Ecological classifications of bryophytes and lichens. In Bryopyhtes and Lichens in a Changing Environment (J. W. Bates \& A. M. Farmer, eds): 1-31. Oxford: Clarendon Press.

Gauslaa, Y. (1985) The ecology of Lobarion pulmonariae and Parmelion caperatae in Quercus dominated forests in South-West Norway. Lichenologist 17: 117-140.

Goward, T. \& Arsenault, A. (2000) Cyanolichen distribution in young unmanaged forests: a dripzone effect? Bryologist 103: 28-37.

Hacker, S. D. \& Gaines, S. D. (1997) Some implication of direct positive interactions for community species diversity. Ecology 78: 1990-2003.

Hannah, L., Lohse, D., Hutchinson, C., Carr, J. L. \& Lankerani, A. (1994) A preliminary inventory of human disturbance of world ecosystems. Ambio 23: 246-250.

Hedenås, H. \& Ericson, L. (2000) Epiphytic macrolichens as conservation indicators: successional sequence in Populus tremula stands. Biological Conservation 93: 43-53.

Hedenås, H., Bolyukh, V. O. \& Jonsson, B. G. (2003) Spatial distribution of epiphytes on Populus tremula in relation to dispersal mode. Fournal of Vegetation Science 14: 233-242.

Holmgren, P. K., Holmgren, N. H. \& Barnett, L. C. (1990) Index Herbariorum. Part I: The Herbaria of the World. 8th Edition. New York: New York Botanical Garden.

Hulbert, S. H. (2004) On misinterpretations of pseudoreplication and related matters: a reply to Oksanen. Oikos 104: 591-597.

Jahns, H. M. \& Ott, S. (1997) Life strategies in lichens - some general considerations. In New Species and Novel Aspects in Ecology and Physiology of Lichens. In Honour of O. L. Lange (L. Kappen, ed.): 49-67. Berlin: Cramer.

Kirk, P. M., Canon, P. F., David, J. C. \& Stalpers, J. A. (2001) Ainsworth E Bisby's Dictionary of the Fungi, 9th Edition. Wallingford: CABI Publishing.

Kuusinen, M. (1996) Cyanobacterial macrolichens on Populus tremula as indicators of forest continuity in
Finland. Biological Conservation 75: 43-49.

Lawrey, J. D. (1984) Biology of Lichenized Fungi. New York: Praeger Publishers.

Nimis, P. L. \& Martellos, S. (2004) Keys to the Lichens of Italy. I. Terricolous Species. Trieste: Edizioni Goliardiche.

Poelt, J. (1969) Bestimmungsschlüssel Europäischer Flechten. Lehre: J. Cramer.

Poelt, J. \& Vězda, A. (1977) Bestimmungsschlüssel Europäischer Flechten. Ergänzungsheft I. Vaduz: J. Cramer.

Poelt, J. \& Vězda, A. (1981) Bestimmungsschlüssel Europäischer Flechten. Ergänzungsheft II. Vaduz: J. Cramer.

Purvis, O. W., Coppins, B. J., Hawksworth, D. L., James, P. W. \& Moore, D. M. (Eds) (1992) The Lichen Flora of Great Britain and Ireland. London: Natural History Museum Publications.

Pyatt, F. B. (1973) Lichen propagules. In The Lichens (V. Ahmadjian \& M. E. Hale, ed.): 117-145. New York: Academic Press.

$\mathrm{R}$ Development Core Team (2006) $R$ : $A$ Language and Environment for Statistical Computing. Vienna: R Foundation for Statistical Computing.

Rabinowitz, D. (1981) Seven forms of rarity. In The Biological Aspects of Rare Plant Conservation: Proceedings of an International Conference (H. Synge, ed.): 205-217. Chichester: Wiley

Rogers, R. W. (1990) Ecological strategies of lichens. Lichenologist 22: 149-162.

Rose, F. (1976) Lichenological indicators of age and environmental continuity in woodlands. In Lichenology: Progress and Problems (D. H. Brown, D. L. Hawksworth \& R. H. Bailey, eds): 279-307. London and New York: Academic Press.

Rosenzweig, M. L. (1995) Species Diversity in Space and Time. Cambridge: Cambridge University Press.

Sala, O. E., Chapin, F. S., Armesto, J. J., Berlow, E., Bloomfield, J., Dirzo, R., Huber-Sanwald, E., Huenneke, L. F., Jackson, R. B., Kinzig, A., Leemans, R., Lodge, D. M., Mooney, H. A., Oesterheld, M., Poff, N. L., Sykes, M. T., Walker, B. H., Walker, M. \& Wall, D. H. (2000) Biodiversity - Global biodiversity scenarios for the year 2100. Science 287: 1770-1774.

Sanderson, E. W., Jaiteh, M., Levy, M. A., Redford, K. H., Wannebo, A. V. \& Woolmer, G. (2002) The human footprint and the last of the wild. BioScience 52: 891-904.

Scheidegger, C., Groner, U., Keller, C. \& Stofer, S. (2002) Biodiversity assessment tools-lichens. In Monitoring with Lichens-Monitoring Lichens (P. L. Nimis, C. Scheidegger \& P. A. Wolseley, eds): 359-365. Dordrecht: Kluwer.

Sillett, S. C. \& McCune, B. (1998) Survival and growth of cyanolichen transplants in douglas-fir forest canopies. Bryologist 101: 20-31.

Sokal, R. R. \& Rohlf, F. J. (1995) Biometry, 3rd Edn. New York: W. H. Freeman and Company.

Tibell, L. (1994) Distribution patterns and dispersal strategies of Caliciales. Botanical fournal of the Linnean Society 116: 159-202. 
Tilman, D., Fargione, J., Wolff, B., D'Antonio, C., Dobson, A., Howarth, R., Schindler, D., Schlesinger, W. H., Simberloff, D. \& Swackhamer, D. (2001) Forecasting agriculturally driven global environmental change. Science 292: 281-284.

Turner II, B. L. (2002) Toward integrated land-change science: advances in 1.5 decades of sustained international research on land-use and land-cover changes. In Challenges of a Changing Earth: Proceedings of the Global Change Open Science Conference, Amsterdam, The Netherlands, 10 - 13 July 2001 (W. Steffen, J. Jäger, D. J. Carson \& C. Bradshow, eds): 21-26. Berlin: Springer.

Turner, M. G., Gardner, R. H. \& O’Neill, R. V. (2001) Landscape Ecology in Theory and Practice: Pattern and Process. New York: Springer Verlag.
Walser, J. C. (2004) Molecular evidence for limited dispersal of vegetative propagules in the epiphytic lichen Lobaria pulmonaria. American foumal of Botany 91: 1273-1276.

Werth, S., Wagner, H., Gugerli, H., Holderegger, R., Csencsics, D., Kalwij, J. \& Scheidegger, C. (2006) Quantifying dispersal and establishment limitation in a population of an epiphytic lichen. Ecology, in press.

Wirth, V. (1995) Die Flechten Baden-Württembergs. Stuttgart: Ulmer.

Wolseley, P. A. (1997) Response of epiphytic lichens to fire in tropical forests of Thailand. In Progress and Problems in Lichenology in the Nineties (R. Türk \& R. Zorer, eds): 165-176. Berlin: J. Cramer. 
Species list with assigned trait values (see Table 1 for details)

Fertility

Propagules

Spore length E shape

Spore septation

Growth form

Photobiont

Substrate specialization

Rarity
1: mostly sterile; 2: mostly fertile (producing regularly ascospores); na: not available

Symbiotic propagules (soredia and/or isidia): 0: lacking; 1: existing; na: not available

Soredia: 0: lacking; 1: existing; na: not available

Isidia: 0: lacking; 1: existing (small thallus fragments were considered as isidia); na: not available

Fungal propagules (ascospores and/or conidia): 0: lacking; 1: existing; na: not available

Conidia: 0: lacking; 1: existing; na: not available

1: short and globose to ellipsoid; 2: short and elongate; 3: long and globose to ellipsoid; 4: long and elongate; na: not available; -: species of the class 'mostly fertile' from trait 'fertility' were considered only

1: no septum; 2: 1-septate; 3: 3-septate or more; 4: muriform; na: not available; -: species of the class 'mostly fertile' from trait 'fertility' were considered only

1: crustose; 2: foliose-adpressed; 3: foliose ascendant; 4: fruticose-erect; 5: fruticose-pendulous

1: green algae (excl. Trentepohlia); 2: Trentepohlia; 3: Nostoc; na: not available

1: specialist (restricted to one substratum); 2: intermediate type (growing on two or three different substrata); 3: generalist (growing on more than three substrata); na: not available (rock, soil, living trees, deadwood and bryophytes were considered as possible substrata)

1: wide distribution and high abundance in most areas; 2 : wide distribution and high abundance in some areas, but rare in others; 3: narrow distribution, high or low abundance; na: not available

\begin{tabular}{|c|c|c|c|c|c|c|c|c|c|c|c|c|}
\hline \multirow[b]{2}{*}{ Species } & \multicolumn{6}{|c|}{ Propagules } & \multirow{2}{*}{ 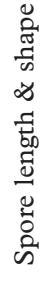 } & \multirow[b]{2}{*}{ 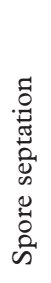 } & \multirow[b]{2}{*}{ 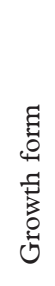 } & \multirow[b]{2}{*}{ 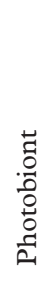 } & \multirow{2}{*}{ 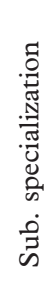 } & \multirow[b]{2}{*}{ 光 } \\
\hline & 鸹 & $\begin{array}{l}\dot{0} \\
\text { 号 } \\
\dot{\text { gे }}\end{array}$ & 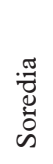 & : & 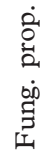 & 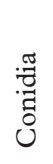 & & & & & & \\
\hline Acarospora badiofusca & 2 & 0 & 0 & 0 & 1 & 0 & 1 & 1 & 1 & 1 & 1 & 2 \\
\hline A. cervina & 2 & 0 & 0 & 0 & 1 & na & na & 1 & 1 & 1 & na & 1 \\
\hline A. fuscata & 2 & 0 & 0 & 0 & 1 & 0 & 2 & 1 & 1 & 1 & 1 & 1 \\
\hline A. glaucocarpa & 2 & 0 & 0 & 0 & 1 & 0 & 2 & 1 & 1 & 1 & 1 & 2 \\
\hline A. heppii & 2 & 0 & 0 & 0 & 1 & 0 & 1 & 1 & 1 & 1 & 1 & 2 \\
\hline A. impressula & 2 & 0 & 0 & 0 & 1 & 0 & 1 & 1 & 1 & 1 & 1 & 2 \\
\hline A. modenensis & 2 & 0 & 0 & 0 & 1 & na & 1 & 1 & 1 & 1 & 1 & 2 \\
\hline
\end{tabular}

Species

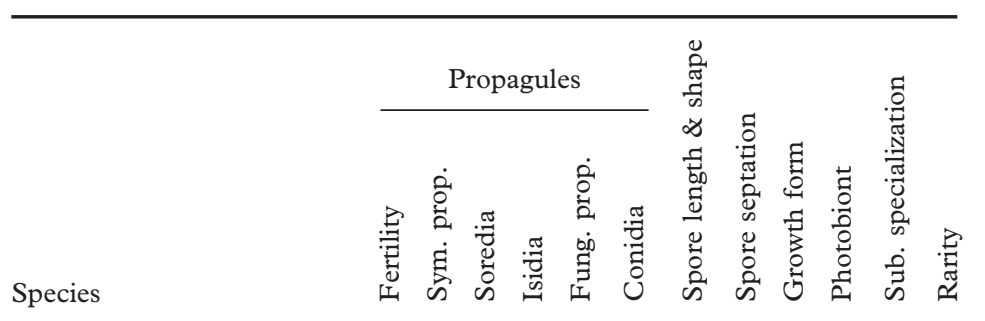

Acarospora nitrophila

A. oligospora

A. scotica

A. smaragdula

A. sulphurata

A. veronensis

Acrocordia gemmata

\begin{tabular}{rllllrllllll}
2 & 0 & 0 & 0 & 1 & 0 & 2 & 1 & 1 & 1 & 1 & 1 \\
2 & 0 & 0 & 0 & 1 & na & 1 & 1 & 1 & 1 & 1 & 2 \\
2 & 0 & 0 & 0 & 1 & na & 1 & 1 & 1 & 1 & 1 & 2 \\
2 & 0 & 0 & 0 & 1 & 0 & 2 & 1 & 1 & 1 & 2 & 2 \\
2 & 0 & 0 & 0 & 1 & na & 1 & 1 & 1 & 1 & 1 & 3 \\
2 & 0 & 0 & 0 & 1 & 0 & 2 & 1 & 1 & 1 & 1 & 2 \\
2 & 0 & 0 & 0 & 1 & 1 & 3 & 2 & 1 & 2 & 1 & 2 \\
\hline
\end{tabular}


Acarospora macrospora A. salweyi

Agonimia tristicula

Amandinea punctata

Anaptychia ciliaris

Anisomeridium biforme

Arthonia cinnabarina

A. didyma

A. elegans

A. intexta

A. lapidicola

A. leucopellaea

A. mediella

A. pruinata

A. radiata

A. spadicea

$A$. vinosa

Arthopyrenia antecellens

A. cinereopruinosa

A. fraxini

A. lapponina

A. orustensis

A. punctiformis

A. ranunculospora

A strontianesis

Arthrosporum populorum

Aspicilia bricconensis

A. caesiocinerea

A. calcarea

A. cinerea

A. contorta

A. crespiana

A. grisea

A. intermutans

A. laevata

A. recedens

A. simoensis

Bacidia absistens

$B$. arceutina

B. arnoldiana

B. assulata

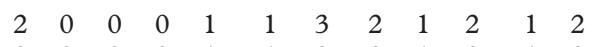
$\begin{array}{llllllllllll}2 & 0 & 0 & 0 & 1 & 1 & 3 & 2 & 1 & 2 & 1 & 2\end{array}$ $\begin{array}{llllllllllll}\text { na } & 1 & 0 & 1 & 0 & 0 & - & - & 1 & 1 & 3 & 1\end{array}$ $\begin{array}{llllllllllll}2 & 0 & 0 & 0 & 1 & 1 & 1 & 2 & 1 & 1 & 2 & 1\end{array}$ $\begin{array}{llllllllllll}2 & 0 & 0 & 0 & 1 & 0 & 3 & 2 & 4 & 1 & 2 & 2\end{array}$

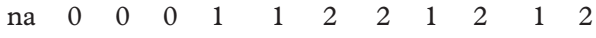
$\begin{array}{llllllllllll}2 & 0 & 0 & 0 & 1 & 1 & 4 & 3 & 1 & 2 & 1 & 2\end{array}$ $\begin{array}{llllllllllll}2 & 0 & 0 & 0 & 1 & 1 & 4 & 2 & 1 & 2 & 1 & 2\end{array}$ $\begin{array}{llllllllllll}2 & 0 & 0 & 0 & 1 & 0 & 4 & 3 & 1 & 2 & 1 & 2\end{array}$ $\begin{array}{llllllllllll}2 & 0 & 0 & 0 & 1 & 1 & 2 & 3 & 1 & - & 1 & 1\end{array}$ $\begin{array}{llllllllllll}2 & 0 & 0 & 0 & 1 & 1 & 1 & 2 & 1 & 2 & 1 & 2\end{array}$ $\begin{array}{llllllllllll}2 & 0 & 0 & 0 & 1 & 0 & 2 & 3 & 1 & 2 & 1 & 2\end{array}$ $\begin{array}{llllllllllll}2 & 0 & 0 & 0 & 1 & 1 & 2 & 3 & 1 & 2 & 1 & 2\end{array}$ $\begin{array}{llllllllllll}2 & 0 & 0 & 0 & 1 & 1 & 4 & 3 & 1 & 2 & 2 & 3\end{array}$ $\begin{array}{llllllllllll}2 & 0 & 0 & 0 & 1 & 1 & 4 & 3 & 1 & 2 & 1 & 1\end{array}$ $\begin{array}{llllllllllll}2 & 0 & 0 & 0 & 1 & 1 & 2 & 2 & 1 & 2 & 1 & 1\end{array}$ $\begin{array}{llllllllllll}2 & 0 & 0 & 0 & 1 & 1 & 2 & 2 & 1 & 2 & 1 & 2\end{array}$ $\begin{array}{llllllllllll}0 & 0 & 0 & 1 & 1 & 4 & 2 & 1 & - & 1 & 3\end{array}$ $\begin{array}{llllllllllll}2 & 0 & 0 & 0 & 1 & 1 & 4 & 2 & 1 & - & 1 & 2 \\ 2 & 0 & 0 & 0 & 1 & 1 & 4 & 2 & 1 & - & 1 & 2\end{array}$ $\begin{array}{lllllllllll}2 & 0 & 0 & 0 & 1 & 1 & 4 & 2 & 1 & - & 1\end{array}$ $\begin{array}{llllllllllll}2 & 0 & 0 & 0 & 1 & \text { na } & 3 & 2 & 1 & \text { na } & \text { na } & 3\end{array}$ $\begin{array}{lllllllllllll}2 & 0 & 0 & 0 & 1 & 0 & 4 & 2 & 1 & - & 1 & 1\end{array}$ $\begin{array}{rrrrrrrrrrrr}2 & 0 & 0 & 0 & 1 & 1 & 2 & 2 & 1 & 2 & 1 & 3 \\ 2 & 0 & 0 & 0 & 1 & 0 & 3 & 2 & 1 & & \text { na } & 2\end{array}$ $\begin{array}{llllllllllll}2 & 0 & 0 & 0 & 1 & 0 & 3 & 2 & 1 & - & \text { na } & 2\end{array}$ $\begin{array}{llllllllllll}2 & 0 & 0 & 0 & 1 & 1 & 2 & 3 & 1 & 1 & 1 & 2\end{array}$ $\begin{array}{llllllllllll}2 & 0 & 0 & 0 & 1 & 1 & 3 & 1 & 1 & 1 & 1 & 2\end{array}$ $\begin{array}{llllllllllll}2 & 0 & 0 & 0 & 1 & 1 & 3 & 1 & 1 & 1 & 1\end{array}$ $\begin{array}{llllllllllll}2 & 0 & 0 & 0 & 1 & 0 & 3 & 1 & 1 & 1 & 1 & 1\end{array}$ $\begin{array}{llllllllllll}2 & 0 & 0 & 0 & 1 & 1 & 3 & 1 & 1 & 1 & 1 & 1\end{array}$ $\begin{array}{llllllllllll}2 & 0 & 0 & 0 & 1 & 1 & 3 & 1 & 1 & 1 & 2 & 3\end{array}$ $\begin{array}{llllllllllll}1 & 1 & 1 & 0 & 0 & 0 & - & - & 1 & 1 & 1 & 2\end{array}$ $\begin{array}{llllllllllll}2 & 0 & 0 & 0 & 1 & 1 & 3 & 1 & 1 & 1 & 1 & 2\end{array}$ $\begin{array}{llllllllllll}2 & 0 & 0 & 0 & 1 & 1 & 3 & 1 & 1 & 1 & 1 & 2\end{array}$ $\begin{array}{lllllllllll}0 & 0 & 0 & 1 & 1 & 1 & 1 & 1 & 1 & 1 & 2\end{array}$ $\begin{array}{llllllllllll}2 & 1 & 1 & 0 & 1 & 0 & 4 & 3 & 1 & 1 & 1 & 2\end{array}$ $\begin{array}{llllllllllll}2 & 0 & 0 & 0 & 1 & 0 & 4 & 3 & 1 & 1 & 3 & 2\end{array}$ \begin{tabular}{cccccccccccc} 
na & 1 & 1 & 0 & 1 & 1 & - & - & 1 & 1 & 2 & 1 \\
2 & 0 & 0 & 0 & 1 & 0 & 4 & 3 & 1 & 1 & & 1 \\
\hline
\end{tabular}
Bacidia beckhausii

B. biatorina

B. chloroticula

B. circumspecta

B. delicata

B. globulosa

incompta

B. inundata

B. laurocerasi

B. naegelii

$B$. phacodes

B. rosella

B. rubella

B. trachona

Baeomyces carneus

B. rufus

Bagliettoa baldensis

Bellemerea cinereofusca

Biatora chrysantha

B. efflorescens

B. helvola

B. subduplex

Bryoria capillaris

B. fuscescens

B. implexa

B. subcana

Buellia aethalea

B. alboatra

B. anomala

$B$. arnoldii

B. badia

$B$. disciformis

B. epipolia

$B$. erubescens

B. griseovirens

B. iberica

B. leptocline

B. ocellata

B. schaereri

Buellia stellulata

B. subdisciformis

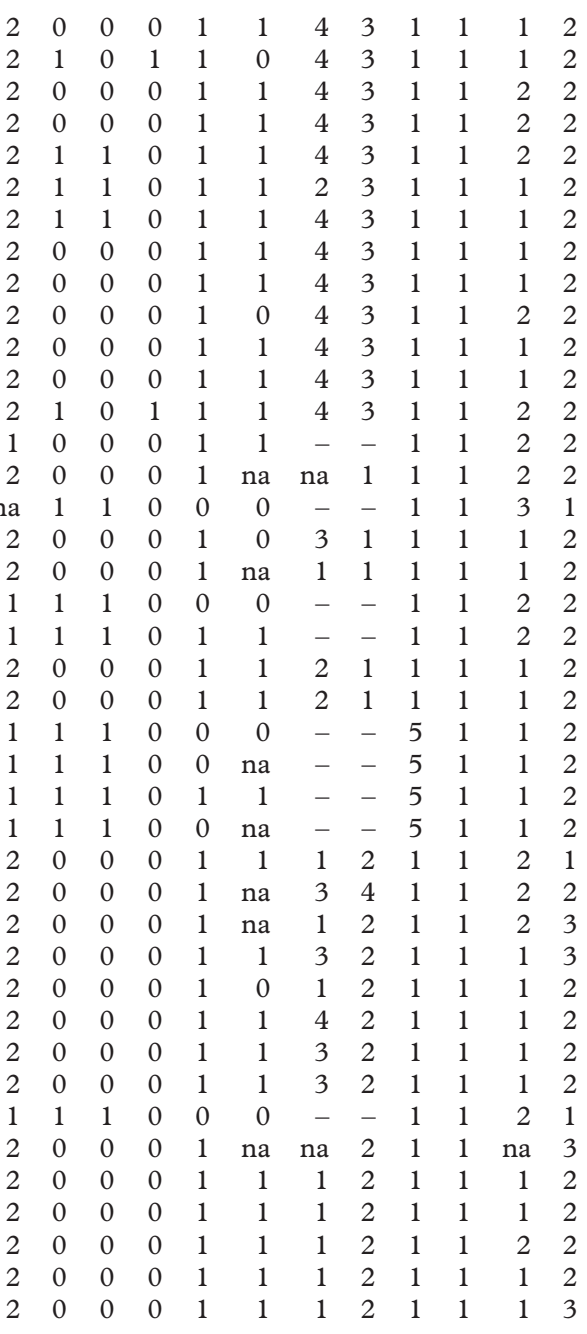

옹

ర్ల 
Species

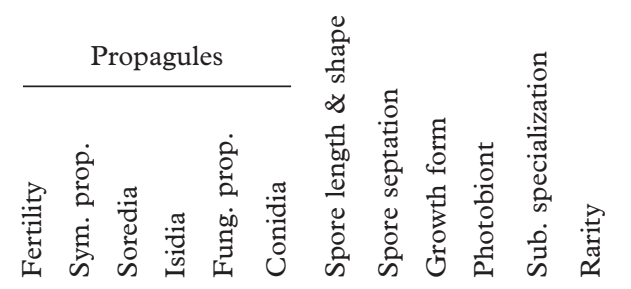

Species

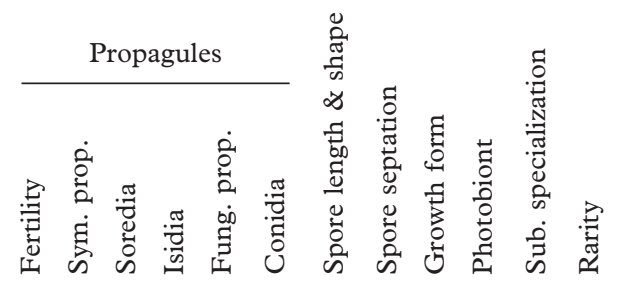

Buellia triseptata

$\begin{array}{llllllllllll}2 & 0 & 0 & 0 & 1 & \text { na } & \text { na } & 2 & 1 & 1 & \text { na } & 2\end{array}$

Caloplaca holocarpa

$\begin{array}{llllllllllll}2 & 0 & 0 & 0 & 1 & 0 & 1 & 2 & 1 & 1 & 2 & 1\end{array}$ Calicium abietinum

$\begin{array}{llllllllllll}2 & 0 & 0 & 0 & 1 & 0 & 1 & 2 & 1 & 1 & 2 & 2 \\ 2 & 0 & 0 & 0 & 1 & 1 & 1 & 2 & 1 & 1 & 2 & 2\end{array}$

C. glaucellum

$\begin{array}{lllll}2 & 0 & 0 & 0 & 1\end{array}$

C. hungarica

C. montanum

$\begin{array}{lllll}2 & 0 & 0 & 0 & 1\end{array}$

C. irrubescens

C. lactea

C. nubigena

C. trabinellum

C. viride

$\begin{array}{llllllllllll}2 & 0 & 0 & 0 & 1 & 0 & 1 & 2 & 1 & 1 & 2 & 2\end{array}$

C. pyracea

C. sinapisperma

Caloplaca aractina

C. biatorina

$\begin{array}{lllll}2 & 0 & 0 & 0 & 1\end{array}$

C. subpallida

C. carphinea

C. cerina

$\begin{array}{llllllllllll}2 & 0 & 0 & 0 & 1 & 0 & 1 & 2 & 1 & 1 & 1 & 3\end{array}$

C. cerinella

C. chalybaea

$\begin{array}{lllll}2 & 0 & 0 & 0\end{array}$

C. teicholyta

C. variabilis

Candelaria concolor

Candelariella aurella

$\begin{array}{lllll}2 & 0 & 0 & 0 \\ 2 & 0 & 0 & 0\end{array}$

$\begin{array}{llllll}1 & 2 & 1 & 1 & 3 & 1 \\ 1 & 2 & 1 & 1 & 1 & 1\end{array}$

C. coralliza

C. chlorina

C. chrysodeta

$\begin{array}{llllllllll}1 & 1 & 1 & 0 & 0 & 0 & -1 & -1 & 1 & 1\end{array}$

C. cirrochroa

$\begin{array}{llll}1 & 1 & 1 & 0\end{array}$

C. deflexa

C. citrina

$\begin{array}{ccccc} & 1 & 1 & 0 & 0 \\ 1 & 1 & 1 & 0 & 0\end{array}$

C. medians

C. reflexa

C. conglomerata

$\begin{array}{lllll}2 & 0 & 0 & 0 & 1\end{array}$

C. vitellina

C. xanthostigma
Carbonea vorticos

C. crenularia

$\begin{array}{llll}2 & 0 & 0 & 0\end{array}$

C. crenulatella

$\begin{array}{llll}2 & 0 & 0 & 0\end{array}$

C. diphyodes

$\begin{array}{lllll}2 & 0 & 0 & 0 & 1\end{array}$

C. dolomiticola

C. ferruginea

$\begin{array}{lllll}2 & 0 & 0 & 0 & 1\end{array}$

$\begin{array}{llll}2 & 0 & 0 & 0 \\ 2 & 0 & 0 & 0\end{array}$

festivella

$\begin{array}{lllll}2 & 0 & 0 & 0 & 1\end{array}$

$\begin{array}{llllll}1 & 2 & 1 & 1 & 1 & 2\end{array}$

Catapyrenium cinereum

C. rufescens

C. squamulosum

Catillaria atomarioides

C. chalybeia

C. flavescens
C. flavorubescens

C. flavovirescens

200000

C. nigroclavata

C. pulverea

C. haematites

$\begin{array}{llllllllllll}2 & 0 & 0 & 0 & 1 & 0 & 3 & 2 & 1 & 1 & 1 & 1\end{array}$

Cetraria aculeatum

C. herbidella

$\begin{array}{rrrrrrrrrrrr}\text { na } & 1 & 0 & 1 & 0 & 0 & - & - & 1 & 1 & 1 & 2\end{array}$

C. chlorophylla

$\begin{array}{llllllllllll}2 & 0 & 0 & 0 & 1 & 0 & 1 & 2 & 1 & 1 & 1 & 1 \\ 2 & 0 & 0 & 0 & 1 & 0 & 1 & 2 & 1 & 1 & 1 & 2\end{array}$

$\begin{array}{llllllllllll}2 & 0 & 0 & 0 & 1 & 0 & 1 & 2 & 1 & 1 & 1 & 2 \\ 2 & 0 & 0 & 0 & 1 & 0 & 3 & 2 & 1 & 1 & 1 & 1\end{array}$

$\begin{array}{llllllllllll}2 & 0 & 0 & 0 & 1 & 0 & 2 & 2 & 1 & 1 & 1 & 3\end{array}$

$\begin{array}{llllllllllll}2 & 0 & 0 & 0 & 1 & 0 & 1 & 2 & 1 & 1 & 2 & 1\end{array}$

$\begin{array}{llllllllllll}2 & 0 & 0 & 0 & 1 & 0 & 3 & 2 & 1 & 1 & 2 & 2\end{array}$

$\begin{array}{llllllllllll}2 & 0 & 0 & 0 & 1 & 0 & 4 & 2 & 1 & 1 & 1 & 2\end{array}$

$\begin{array}{llllllllllll}2 & 1 & 1 & 0 & 1 & 0 & 3 & 2 & 1 & 1 & 1 & 1\end{array}$

$\begin{array}{llllllllllll}2 & 0 & 0 & 0 & 1 & 0 & 1 & 2 & 1 & 1 & 1 & 1\end{array}$

$\begin{array}{llllllllllll}1 & 1 & 0 & 1 & 1 & 1 & - & - & 3 & 1 & 2 & 1\end{array}$

$\begin{array}{llllllllllll}1 & 1 & 0 & 1 & 1 & 1 & - & - & 3 & 1 & 2 & 1 \\ 2 & 0 & 0 & 0 & 1 & 0 & 2 & 1 & 1 & 1 & 2 & 1\end{array}$

$\begin{array}{llllllllllll}1 & 1 & 0 & 1 & 0 & 0 & - & - & 1 & 1 & 1 & 2\end{array}$

$\begin{array}{llllllllllll}2 & 0 & 0 & 0 & 1 & 0 & 2 & 1 & 1 & 1 & 1 & 2\end{array}$

$\begin{array}{llllllllllll}1 & 1 & 0 & 1 & 0 & 0 & - & - & 1 & 1 & 1 & 2\end{array}$

$\begin{array}{llllllllllll}1 & 1 & 1 & 0 & 0 & 0 & - & - & 1 & 1 & 1 & 1\end{array}$

$\begin{array}{llllllllllll}\text { na } & 0 & 0 & 0 & 1 & 1 & - & - & 1 & 1 & 2 & 1\end{array}$

$\begin{array}{llllllllllll}1 & 1 & 0 & 1 & 0 & 0 & - & - & 1 & 1 & 1 & 1\end{array}$

$\begin{array}{llllllllllll}2 & 0 & 0 & 0 & 1 & 1 & 2 & 1 & 1 & \text { na } & 1 & 2\end{array}$

$\begin{array}{llllllllllll}2 & 0 & 0 & 0 & 1 & 0 & 4 & 1 & 2 & 1 & 2 & 2\end{array}$

$\begin{array}{llllllllllll}2 & 0 & 0 & 0 & 1 & 1 & 3 & 1 & 2 & 1 & 2 & 2\end{array}$

$\begin{array}{llllllllllll}2 & 0 & 0 & 0 & 1 & 1 & 1 & 1 & 2 & 1 & 1 & 3\end{array}$

$\begin{array}{llllllllllll}2 & 0 & 0 & 0 & 1 & 1 & 1 & 1 & 2 & 1 & 1 & 3 \\ 2 & 0 & 0 & 0 & 1 & 0 & 2 & 2 & 1 & 1 & 1 & 2\end{array}$

$\begin{array}{llllllllllll}2 & 0 & 0 & 0 & 1 & 1 & 2 & 2 & 1 & 1 & 2 & 2\end{array}$

$\begin{array}{llllllllllll}2 & 0 & 0 & 0 & 1 & 0 & 2 & 2 & 1 & 1 & 1 & 2\end{array}$

$\begin{array}{llllllllllll}1 & 1 & 1 & 0 & 0 & 0 & - & - & 1 & 2 & 3 & 2\end{array}$

$\begin{array}{llllllllllll}1 & 1 & 0 & 1 & 0 & 0 & - & - & 4 & 1 & 2 & 2\end{array}$ 
\begin{tabular}{lllllllllllll}
\hline Cladonia merochlorophaea & 2 & 1 & 1 & 1 & 1 & 1 & - & - & 4 & 1 & 2 & 1
\end{tabular}

Cetraria merilli

C. muricatum

Cetrelia cetrarioides agg.

Chaenotheca brunneola

C. chrysocephala

C. ferruginea

C. furfuracea

C. phaeocephala

C. stemonea

C. trichialis

C. xyloxena

Chrysothrix candelaris

C. chlorina

C. flavovirens

Cladonia acuminata

C. amaurocrae

C. arbuscula

C. bellidiflora

C. borealis

C. botrytes

C. carneola

C. cenotea

C. cervicornis

C. coccifera

C. coniocraea auct.

C. convoluta

C. cornuta

C. crispata

C. deformis

C. digitata

C. diversa

C. fimbriata

C. foliacea

C. furcata

C. glauca

gracilis

C. luteoalba

C. macilenta

C. macroceras

C. macrophylla

C. magyarica

\begin{tabular}{rrrrrrrrrrrr}
1 & 1 & 0 & 1 & 0 & 0 & - & - & 4 & 1 & na & 3 \\
1 & 1 & 0 & 1 & 1 & 1 & - & - & 4 & 1 & 3 & 2 \\
1 & 1 & 1 & 0 & 0 & 0 & - & - & 3 & 1 & 1 & 2 \\
2 & 0 & 0 & 0 & 1 & 0 & 1 & 1 & 1 & 1 & 2 & 2 \\
2 & 0 & 0 & 0 & 1 & 0 & 1 & 1 & 1 & 1 & 2 & 2 \\
2 & 0 & 0 & 0 & 1 & 0 & 1 & 1 & 1 & 1 & 2 & 2 \\
2 & 1 & 1 & 0 & 1 & 0 & 1 & 1 & 1 & 1 & 2 & 2 \\
2 & 0 & 0 & 0 & 1 & 0 & 1 & 1 & 1 & 1 & 2 & 2 \\
2 & 1 & 1 & 0 & 1 & 0 & 1 & 1 & 1 & 1 & 2 & 2 \\
2 & 0 & 0 & 0 & 1 & 0 & 1 & 1 & 1 & 1 & 2 & 2 \\
2 & 0 & 0 & 0 & 1 & 0 & 1 & 1 & 1 & 1 & 1 & 2 \\
1 & 1 & 1 & 0 & 0 & 0 & - & - & 1 & 1 & 2 & 2 \\
1 & 1 & 1 & 0 & 0 & 0 & - & - & 1 & 1 & 2 & 2 \\
1 & 1 & 1 & 0 & 0 & 0 & - & - & 1 & 1 & na & 3 \\
1 & 0 & 0 & 0 & 1 & 1 & - & - & 4 & 1 & na & 3 \\
1 & 0 & 0 & 0 & 1 & 1 & - & - & 4 & 1 & 1 & 2 \\
1 & 1 & 0 & 1 & 1 & 1 & - & - & 4 & 1 & 1 & 2 \\
2 & 0 & 0 & 0 & 1 & 1 & - & - & 4 & 1 & 1 & 2 \\
1 & na & na & na & 1 & 1 & - & - & 4 & 1 & 3 & 3 \\
2 & 0 & 0 & 0 & 1 & 1 & - & - & 4 & 1 & 1 & 2 \\
1 & 1 & 1 & 0 & 1 & 1 & - & - & 4 & 1 & 2 & 2 \\
1 & 1 & 1 & 0 & 1 & 1 & - & - & 4 & 1 & 2 & 1 \\
1 & 1 & 0 & 1 & 1 & 1 & - & - & 4 & 1 & 1 & 2 \\
2 & 1 & 1 & 0 & 1 & 1 & - & - & 4 & 1 & 3 & 2 \\
1 & 1 & 1 & 0 & 1 & 1 & - & - & 4 & 1 & 2 & 1 \\
1 & 1 & 0 & 1 & 1 & 1 & - & - & 4 & 1 & 1 & 2 \\
1 & 1 & 1 & 1 & 1 & 1 & - & - & 4 & 1 & 2 & 2 \\
2 & 1 & 0 & 1 & 1 & 1 & - & - & 4 & 1 & 1 & 2 \\
1 & 1 & 1 & 0 & 1 & 1 & - & - & 4 & 1 & 2 & 2 \\
1 & 1 & 1 & 0 & 1 & 1 & - & - & 4 & 1 & 2 & 2 \\
1 & 1 & 1 & 1 & 1 & 1 & - & - & 4 & 1 & 2 & 2 \\
1 & 1 & 1 & 0 & 1 & 1 & - & - & 4 & 1 & 2 & 1 \\
1 & 1 & 0 & 1 & 1 & 1 & - & - & 4 & 1 & 2 & 2 \\
2 & 1 & 0 & 1 & 1 & 1 & - & - & 4 & 1 & 2 & 2 \\
1 & 1 & 1 & 0 & 1 & 1 & - & - & 4 & 1 & 2 & 2 \\
1 & 1 & 0 & 1 & 1 & 1 & - & - & 4 & 1 & 2 & 2 \\
1 & 1 & 1 & 0 & 1 & 1 & - & - & 4 & 1 & 3 & 2 \\
2 & 1 & 1 & 0 & 1 & 1 & - & - & 4 & 1 & 3 & 2 \\
1 & 1 & 0 & 1 & 1 & 1 & - & - & 4 & 1 & 1 & 2 \\
2 & 1 & 0 & 1 & 1 & 1 & - & - & 4 & 1 & 2 & 2 \\
1 & 1 & 1 & 1 & 1 & 1 & - & - & 4 & 1 & na & 3 \\
\hline & & & & & & & & & & \\
1 &
\end{tabular}

C. metacorallifera

C. phyllophora

C. pleurota

C. polydactyla

C. portentosa

C. pyxidata

C. ramulosa

C. rangiferina

C. rangiformis

C. squamosa

C. stellaris

C. subcervicornis

C. subulata

C. sulphurina

C. symphycarpa

C. uncialis

Clauzadea monticola

Clauzadeana macula

Cliostomum griffithii

Coelocaulon crespoae

Collema auriforme

C. crispum

C. cristatum

C. fasciculare

C. flaccidum

C. furfuraceum

C. fuscovirens

C. nigrescens

C. parvum

C. polycarpon

C. subflaccidum

C. subnigrescens

C. tenax

C. undulatum

Cystocoleus ebeneus

Degelia atlantica

D. plumbea

Dendriscocaulon umhausense

Dermatocarpon miniatum

Dibaeis baeomyces $\begin{array}{llllllllllll}2 & 1 & 1 & 1 & 1 & 1 & - & - & 4 & 1 & 2 & 2\end{array}$

$\begin{array}{llllllllllll}1 & 1 & 1 & 1 & 1 & 1 & - & - & 4 & 1 & 2 & 2\end{array}$

$\begin{array}{llllllllllll}2 & 1 & 1 & 0 & 1 & 1 & - & - & 4 & 1 & 2 & 2\end{array}$

$\begin{array}{lllllllllllll}2 & 1 & 1 & 0 & 1 & 1 & - & - & 4 & 1 & 2 & 2\end{array}$

$\begin{array}{llllllllllll}1 & 1 & 0 & 1 & 0 & 0 & - & - & 4 & 1 & 1 & 2\end{array}$

$\begin{array}{llllllllllll}2 & 1 & 1 & 0 & 1 & 1 & - & - & 4 & 1 & 3 & 1\end{array}$

$\begin{array}{llllllllllll}2 & 1 & 1 & 1 & 1 & 1 & - & - & 4 & 1 & 2 & 2\end{array}$

$\begin{array}{llllllllllll}1 & 1 & 0 & 1 & 1 & 1 & - & - & 4 & 1 & 2 & 2\end{array}$

$\begin{array}{llllllllllll}1 & 1 & 0 & 1 & 1 & 1 & - & - & 4 & 1 & 1 & 2\end{array}$

$\begin{array}{llllllllllll}1 & 1 & 0 & 1 & 1 & 1 & - & - & 4 & 1 & 3 & 2\end{array}$

$\begin{array}{llllllllllll}1 & 1 & 0 & 1 & 1 & 1 & - & - & 4 & 1 & 1 & 2\end{array}$

$\begin{array}{lllllllllllll}2 & 1 & 0 & 1 & 1 & 1 & - & - & 4 & 1 & 2 & 2\end{array}$

$\begin{array}{llllllllllll}1 & 1 & 1 & 1 & 1 & 1 & - & - & 4 & 1 & 2 & 2\end{array}$

$\begin{array}{llllllllllll}1 & 1 & 1 & 0 & 1 & 1 & - & - & 4 & 1 & 2 & 2\end{array}$

$\begin{array}{lllllllllllll}1 & 1 & 0 & 1 & 1 & 1 & - & - & 4 & 1 & 1 & 1\end{array}$

$\begin{array}{lllllllllllll}1 & 1 & 0 & 1 & 1 & 1 & - & - & 4 & 1 & 2 & 3\end{array}$

$\begin{array}{llllllllllll}2 & 0 & 0 & 0 & 1 & 0 & 1 & 1 & 1 & 1 & 1 & 2\end{array}$

$\begin{array}{llllllllllll}2 & 0 & 0 & 0 & 1 & 0 & 1 & 1 & 1 & 1 & 1 & 2\end{array}$

$\begin{array}{llllllllllll}2 & 0 & 0 & 0 & 1 & 1 & 2 & 2 & 1 & 1 & 2 & 2\end{array}$

$\begin{array}{llllllllllll}1 & 1 & 0 & 1 & 0 & 0 & - & - & 2 & 3 & 2 & 2\end{array}$

$\begin{array}{llllllllllll}1 & 1 & 0 & 1 & 0 & 0 & - & - & 3 & 3 & 2 & 1\end{array}$

$\begin{array}{llllllllllll}2 & 1 & 0 & 1 & 1 & 0 & 3 & 4 & 2 & 3 & 2 & 1\end{array}$

$\begin{array}{llllllllllll}2 & 0 & 0 & 0 & 1 & 0 & 4 & 3 & 2 & 3 & 2 & 2\end{array}$

$\begin{array}{llllllllllll}1 & 1 & 0 & 1 & 0 & 0 & - & - & 2 & 3 & 2 & 2\end{array}$

$\begin{array}{llllllllllll}1 & 1 & 0 & 1 & 0 & 0 & - & - & 2 & 3 & 2 & 2\end{array}$

$\begin{array}{llllllllllll}1 & 1 & 0 & 1 & 0 & 0 & - & - & 2 & 3 & 1 & 2\end{array}$

$\begin{array}{llllllllllll}2 & 0 & 0 & 0 & 1 & 0 & 4 & 3 & 2 & 3 & 2 & 2\end{array}$

$\begin{array}{llllllllllll}1 & 1 & 0 & 1 & 1 & 1 & - & - & 2 & 3 & 1 & 2\end{array}$

$\begin{array}{llllllllllll}2 & 0 & 0 & 0 & 1 & 0 & 4 & \text { na } & 3 & 3 & 1 & 1\end{array}$

$\begin{array}{llllllllllll}1 & 1 & 0 & 1 & 0 & 0 & - & - & 2 & 3 & 2 & 2\end{array}$

$\begin{array}{llllllllllll}2 & 0 & 0 & 0 & 1 & 0 & 4 & 3 & 2 & 3 & 2 & 2\end{array}$

$\begin{array}{llllllllllll}2 & 1 & 0 & 1 & 1 & 1 & 4 & \text { na } & 2 & 3 & 2 & 1\end{array}$

$\begin{array}{llllllllllll}2 & 0 & 0 & 0 & 1 & 0 & 4 & 3 & 2 & 3 & 1 & 1\end{array}$

$\begin{array}{llllllllllll}1 & 1 & 0 & 1 & 0 & 0 & - & - & 1 & 2 & 2 & 2\end{array}$

$\begin{array}{llllllllllll}1 & 1 & 0 & 1 & 0 & 0 & - & - & 2 & 3 & 2 & 3\end{array}$

$\begin{array}{llllllllllll}2 & 0 & 0 & 0 & 1 & 1 & 3 & 1 & 2 & 3 & 2 & 3\end{array}$

$\begin{array}{llllllllllll}1 & 1 & 0 & 1 & 0 & 0 & - & - & 4 & 3 & \text { na } & 3\end{array}$

$\begin{array}{llllllllllll}2 & 0 & 0 & 0 & 1 & 1 & 1 & 1 & 3 & 1 & 1 & 2\end{array}$

$\begin{array}{lllllllllllll}2 & 1 & 0 & 1 & 1 & 1 & 4 & 1 & 1 & 1 & 1 & 1\end{array}$

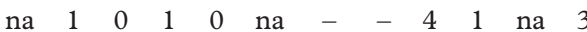


Species

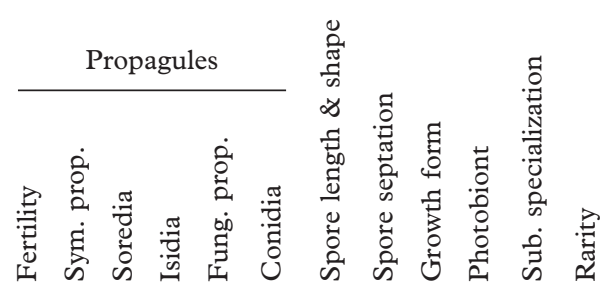

Species

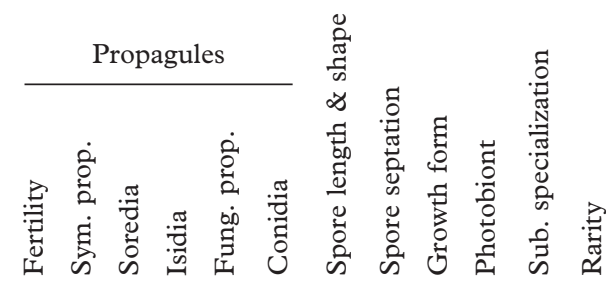

Dimerella lutea

D. pineti

Diploicia canescens

Diploschistes euganeus

D. gypsaceus

D. muscorum

D. scruposus

Enterographa crassa

Evernia divaricata

E. prunastri

Farnoldia jurana

Fellhanera bouteillei

Fuscidea arboricola

$F$. cyathoides

F. lightfootii

F. praeruptorum

F. pusilla

Graphina anguina

Graphis elegans

G. scripta

Gyalecta flotowii

G. jenensis

G. truncigena

Gyalideopsis anastomosans

Haematomma ochroleucum

Halecania giraltiae

$H$. viridescens

Heterodermia obscurata

H. speciosa $\begin{array}{llllllllllll}2 & 0 & 0 & 0 & 1 & 1 & 2 & 2 & 1 & 2 & 3 & 2\end{array}$

$\begin{array}{llllllllllll}2 & 0 & 0 & 0 & 1 & 1 & 2 & 2 & 1 & 2 & 3 & 1\end{array}$

$\begin{array}{llllllllllll}1 & 1 & 1 & 0 & 1 & 1 & 1 & 2 & 1 & 1 & 2 & 2\end{array}$

$\begin{array}{llllllllllll}2 & 0 & 0 & 0 & 1 & 0 & 3 & 4 & 1 & 1 & 1 & 2\end{array}$

$\begin{array}{llllllllllll}2 & 0 & 0 & 0 & 1 & 0 & 3 & 4 & 1 & 1 & 1 & 2\end{array}$

$\begin{array}{llllllllllll}2 & 0 & 0 & 0 & 1 & 0 & 3 & 4 & 1 & 1 & 2 & 1\end{array}$

$\begin{array}{llllllllllll}2 & 0 & 0 & 0 & 1 & 1 & 3 & 4 & 1 & 1 & 1 & 1 \\ 2 & 0 & 0 & 0 & 1 & 1 & 4 & 3 & 1 & 2 & 2 & 3\end{array}$

$\begin{array}{llllllllllll}2 & 0 & 0 & 0 & 1 & 1 & 4 & 3 & 1 & 2 & 2 & 3 \\ 1 & 0 & 0 & 0 & 0 & 0 & - & - & 5 & 1 & 1 & 2\end{array}$

$\begin{array}{llllllllllll}1 & 1 & 1 & 0 & 0 & 0 & - & - & 4 & 1 & 3 & 1\end{array}$

$\begin{array}{llllllllllll}2 & 0 & 0 & 0 & 1 & 1 & 3 & 1 & 1 & 1 & 1 & 2\end{array}$

$\begin{array}{llllllllllll}2 & 1 & 1 & 0 & 1 & 1 & 2 & 2 & 1 & 1 & 1 & 2\end{array}$

$\begin{array}{llllllllllll}1 & 1 & 1 & 0 & 0 & 0 & - & - & 1 & 1 & 1 & 2\end{array}$

$\begin{array}{llllllllllll}2 & 0 & 0 & 0 & 1 & 1 & 1 & 1 & 1 & 1 & 2 & 2 \\ 2 & 1 & 1 & 0 & 1 & 0 & 1 & 1 & 1 & 1 & 1 & 2\end{array}$

$\begin{array}{llllllllllll}1 & 1 & 1 & 0 & 0 & 0 & - & - & 1 & 1 & 1 & 2\end{array}$

$\begin{array}{llllllllllll}1 & 1 & 1 & 0 & 0 & 0 & - & - & 1 & 1 & 1 & 2\end{array}$

$\begin{array}{llllllllllll}2 & 0 & 0 & 0 & 1 & 0 & 3 & 3 & 1 & 2 & 1 & 3\end{array}$

$\begin{array}{llllllllllll}2 & 0 & 0 & 0 & 1 & 0 & 4 & 3 & 1 & 2 & 2 & 3\end{array}$

$\begin{array}{llllllllllll}2 & 0 & 0 & 0 & 1 & 1 & 4 & 3 & 1 & 2 & 1 & 1\end{array}$

$\begin{array}{llllllllllll}2 & 0 & 0 & 0 & 1 & 0 & 1 & 3 & 1 & 2 & 1 & 2\end{array}$

$\begin{array}{llllllllllll}2 & 0 & 0 & 0 & 1 & 0 & 1 & 4 & 1 & 2 & 2 & 1\end{array}$

$\begin{array}{llllllllllll}2 & 0 & 0 & 0 & 1 & 0 & 4 & 4 & 1 & 2 & 1 & 2\end{array}$

$\begin{array}{llllllllllll}1 & 1 & 0 & 1 & 0 & 0 & - & - & 1 & 1 & 3 & 2\end{array}$

$\begin{array}{rrrrrrrrrrrr}1 & 1 & 1 & 0 & 1 & 1 & - & - & 1 & 1 & 2 & 2 \\ 1 & 1 & 1 & 0 & 1 & 1 & - & - & 1 & 1 & \text { na } & 3\end{array}$

$\begin{array}{llllllllllll}1 & 1 & 1 & 0 & 0 & 0 & - & - & 1 & 1 & 1 & 2\end{array}$

$\begin{array}{llllllllllll}1 & 1 & 1 & 0 & 0 & 0 & - & - & 2 & 1 & 3 & 3\end{array}$

$\begin{array}{lllllllllllll}1 & 1 & 1 & 0 & 0 & 0 & - & - & 2 & 1 & 2 & 3\end{array}$
Hyperphyscia adglutinata

Hypocenomyce caradocensis

H. friesii

H. scalaris

H. sorophora

stoechadiana

Hypogymnia bitteri

H. farinacea

H. physodes

H. tubulosa

H. vittata

Icmadophila ericetorum

Immersaria athroocarpa

Imshaugia aleurites

Ionaspis epulotica

I. melanocarpa

Tewia carrollii

Koerbera biformis

Lasallia pustulata

Lecanactis abietina

L. latebrarum

L. lyncea

L. premnea

Lecania cyrtella

L. fuscella

L. inundata

Lecanora aff. expallens

L. albella

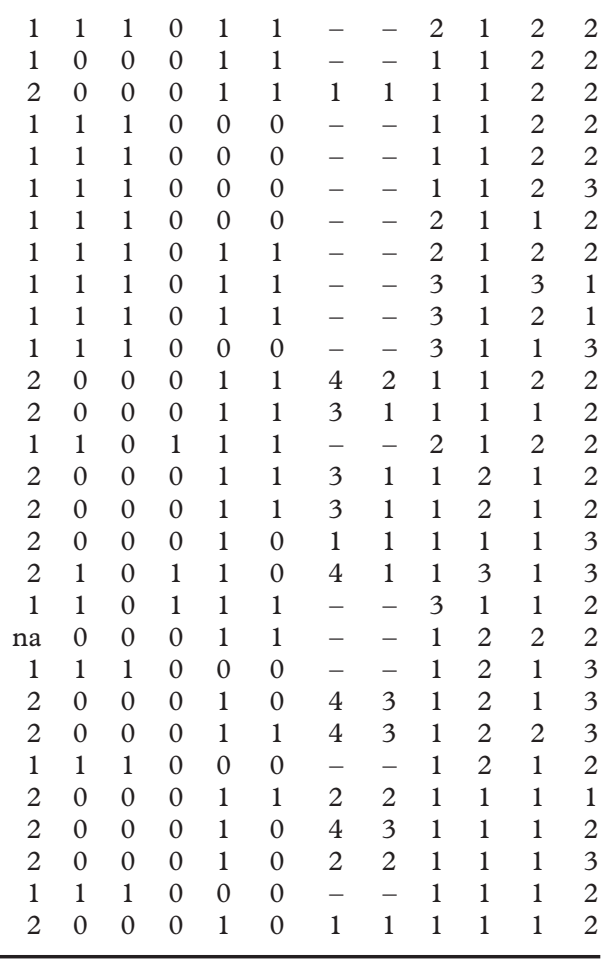

 


\begin{tabular}{|c|c|c|c|c|c|c|c|c|c|c|c|}
\hline Lecanora albescens & 2 & 0 & 0 & 0 & 1 & 1 & 1 & 1 & 1 & 1 & 1 \\
\hline L. allophana & 2 & 0 & 0 & 0 & 1 & 0 & 3 & 1 & 1 & 1 & 1 \\
\hline L. argentata & 2 & 0 & 0 & 0 & 1 & 0 & 1 & 1 & 1 & 1 & 1 \\
\hline L. bolcana & 2 & 0 & 0 & 0 & 1 & 0 & 1 & 1 & 1 & 1 & 1 \\
\hline L. cadubriae & 2 & 0 & 0 & 0 & 1 & 1 & 2 & 1 & 1 & 1 & 2 \\
\hline L. caesiosora & 1 & 1 & 1 & 0 & 1 & 1 & - & - & 1 & 1 & 1 \\
\hline L. campestris & 2 & 0 & 0 & 0 & 1 & 1 & 4 & 1 & 1 & 1 & 2 \\
\hline L. carpinea & 2 & 0 & 0 & 0 & 1 & 1 & 1 & 1 & 1 & 1 & 2 \\
\hline L. cenisia & 2 & 0 & 0 & 0 & 1 & 0 & 1 & 1 & 1 & 1 & 1 \\
\hline L. chlarotera & 2 & 0 & 0 & 0 & 1 & 1 & 1 & 1 & 1 & 1 & 2 \\
\hline L. circumborealis & 2 & 0 & 0 & 0 & 1 & 0 & 1 & 1 & 1 & 1 & 2 \\
\hline L. compallens & 1 & 1 & 1 & 0 & 0 & 0 & na & 1 & 1 & na & na \\
\hline L. confusa & 2 & 0 & 0 & 0 & 1 & 0 & 2 & 1 & 1 & 1 & 2 \\
\hline L. conizaeoides & na & 1 & 1 & 0 & 1 & 1 & - & - & 1 & 1 & 3 \\
\hline L. dispersa & 2 & 0 & 0 & 0 & 1 & 0 & 1 & 1 & 1 & 1 & 2 \\
\hline L. expallens & na & 1 & 1 & 0 & 0 & 0 & - & - & 1 & 1 & 2 \\
\hline L. expersa & 1 & 1 & 1 & 0 & 1 & 1 & - & - & 1 & 1 & 2 \\
\hline L. farinaria & 1 & 1 & 1 & 0 & 0 & 0 & - & - & 1 & na & 2 \\
\hline L. gangaleoides & 2 & 0 & 0 & 0 & 1 & 0 & 1 & 1 & 1 & 1 & 2 \\
\hline L. hagenii aggr. & 2 & 0 & 0 & 0 & 1 & 1 & 1 & 1 & 1 & 1 & 2 \\
\hline L. hispanica & na & 0 & 0 & 0 & 0 & na & - & - & 1 & 1 & na \\
\hline L. horiza aggr. & 2 & 0 & 0 & 0 & 1 & 0 & 1 & 1 & 1 & 1 & 1 \\
\hline L. hypoptella & 2 & 0 & 0 & 0 & 1 & 1 & 2 & 1 & 1 & 1 & 2 \\
\hline L. intricata & 2 & 0 & 0 & 0 & 1 & 1 & 1 & 1 & 1 & 1 & 2 \\
\hline L. intumescens & 2 & 0 & 0 & 0 & 1 & 0 & 1 & 1 & 1 & 1 & 1 \\
\hline L. jamesii & 1 & 1 & 1 & 0 & 0 & 0 & - & - & 1 & 1 & 2 \\
\hline L. leptyrodes & 2 & 0 & 0 & 0 & 1 & 0 & 1 & 1 & 1 & 1 & 1 \\
\hline L. meridionalis & 2 & 0 & 0 & 0 & 1 & 0 & 1 & 1 & 1 & 1 & 2 \\
\hline L. muralis & 2 & 0 & 0 & 0 & 1 & 1 & 1 & 1 & 1 & 1 & 2 \\
\hline L. norvegica & 1 & 0 & 0 & 0 & 0 & 0 & - & - & 1 & na & 1 \\
\hline L. orosthea & 1 & 1 & 1 & 0 & 1 & 1 & - & - & 1 & 1 & 2 \\
\hline L. persimilis & 2 & 0 & 0 & 0 & 1 & 0 & 1 & 1 & 1 & 1 & 1 \\
\hline L. piniperda & 2 & 0 & 0 & 0 & 1 & 1 & 2 & 1 & 1 & na & 2 \\
\hline L. polytropa & 2 & 0 & 0 & 0 & 1 & 1 & 1 & 1 & 1 & 1 & 2 \\
\hline L. populicola & 2 & 0 & 0 & 0 & 1 & 0 & 1 & 1 & 1 & 1 & 1 \\
\hline L. praesistens & 2 & 0 & 0 & 0 & 1 & 0 & 1 & 1 & 1 & 1 & 1 \\
\hline L. pulicaris & 2 & 0 & 0 & 0 & 1 & 0 & 1 & 1 & 1 & 1 & 2 \\
\hline L. rubicunda & 2 & 0 & 0 & 0 & 1 & 0 & 1 & 1 & 1 & na & na \\
\hline L. rugosella & 2 & 1 & 0 & 1 & 1 & 0 & 1 & 1 & 1 & 1 & 2 \\
\hline L. rupicola & 2 & 0 & 0 & 0 & 1 & 1 & 1 & 1 & 1 & 1 & 1 \\
\hline L. saligna & 2 & 0 & 0 & 0 & 1 & 1 & 1 & 1 & 1 & 1 & 2 \\
\hline
\end{tabular}

Lecanora sambuci L. soralifera L. strobilina

L. subcarpinea

L. subintricata

L. subrugosa

L. sulphurea

L. symmicta aggr.

L. varia

Lecidea albohyalina

L. amaurospoda

L. auriculata

L. botryosa

L. cinnabarina

L. confluens

L. exigua

L. fuscoatra

L. hypopta

L. lactea

L. lapicida

L. lithophila

L. lurida

L. nylanderi

L. plana

L. sarcogynoides

L. swartzioidea

L. symmictella

Lecidella carpathica

L. elaeochroma

L. flavosorediata

L. pulveracea

L. scabra

L. stigmatea

L. subincongrua

Lepraria caesioalba

L. eburnea

L. elobata

L. incana

L. jackii

L. lobificans
L. neglecta $\begin{array}{lllllllllllll}2 & 0 & 0 & 0 & 1 & 1 & 1 & 1 & 1 & 1 & 1 & 1 & 8 \\ 1 & 1 & 1 & 0 & 0 & 0 & - & - & 1 & 1 & 2 & 2 & \circ\end{array}$

$\begin{array}{llllllllllll}2 & 1 & 1 & 0 & 1 & 1 & 1 & 1 & 1 & 1 & 2 & 2\end{array}$

$\begin{array}{llllllllllll}2 & 0 & 0 & 0 & 1 & 1 & 1 & 1 & 1 & 1 & 1 & 2\end{array}$

$\begin{array}{llllllllllll}2 & 0 & 0 & 0 & 1 & 1 & 1 & 1 & 1 & \text { na } & 2 & 2\end{array}$

$\begin{array}{llllllllllll}2 & 0 & 0 & 0 & 1 & 1 & 1 & 1 & 1 & 1 & 1 & 1\end{array}$

$\begin{array}{llllllllllll}2 & 0 & 0 & 0 & 1 & 1 & 1 & 1 & 1 & \text { na } & 1 & 2\end{array}$

$\begin{array}{llllllllllll}2 & 0 & 0 & 0 & 1 & 1 & 2 & 1 & 1 & 1 & 2 & 1\end{array}$

$\begin{array}{llllllllllll}2 & 0 & 0 & 0 & 1 & 1 & 1 & 1 & 1 & 1 & 2 & 2\end{array}$

$\begin{array}{llllllllllll}2 & 0 & 0 & 0 & 1 & 0 & 2 & 1 & 1 & 1 & 1 & 2\end{array}$

$\begin{array}{llllllllllllllllll}1 & 1 & 1 & 0 & 0 & 0 & - & - & 1 & 1 & 2 & 2\end{array}$

$\begin{array}{llllllllllll}2 & 0 & 0 & 0 & 1 & 1 & 2 & 1 & 1 & \text { na } & 1 & 2\end{array}$

$\begin{array}{llllllllllll}2 & 1 & 1 & 0 & 1 & 0 & 2 & 1 & 1 & \text { na } & 2 & 2\end{array}$

$\begin{array}{llllllllllll}1 & 1 & 1 & 0 & 0 & 0 & - & - & 1 & 1 & 1 & 2\end{array}$

$\begin{array}{llllllllllll}2 & 0 & 0 & 0 & 1 & 1 & 1 & 1 & 1 & 1 & 1 & 2\end{array}$

$\begin{array}{llllllllllll}2 & 0 & 0 & 0 & 1 & 0 & 1 & 1 & 1 & 1 & 1 & 2\end{array}$

$\begin{array}{llllllllllll}2 & 0 & 0 & 0 & 1 & 1 & 1 & 1 & 1 & 1 & 2 & 2\end{array}$

$\begin{array}{llllllllllll}2 & 0 & 0 & 0 & 1 & 1 & 1 & 1 & 1 & 1 & 2 & 2\end{array}$

$\begin{array}{llllllllllll}2 & 0 & 0 & 0 & 1 & 1 & 1 & 1 & 1 & 1 & 1 & 2\end{array}$

$\begin{array}{llllllllllll}2 & 0 & 0 & 0 & 1 & 1 & 1 & 1 & 1 & 1 & 1 & 2\end{array}$

$\begin{array}{llllllllllll}2 & 0 & 0 & 0 & 1 & 1 & 1 & 1 & 1 & 1 & 1 & 2\end{array}$

na $\begin{array}{llllllllllll}0 & 0 & 0 & 1 & 1 & - & - & 1 & 1 & 2 & 2\end{array}$

$\begin{array}{llllllllllll}1 & 1 & 1 & 0 & 0 & 0 & - & - & 1 & 1 & 2 & 2\end{array}$

$\begin{array}{llllllllllll}2 & 0 & 0 & 0 & 1 & 1 & 1 & 1 & 1 & 1 & 1 & 2\end{array}$

$\begin{array}{llllllllllll}2 & 0 & 0 & 0 & 1 & 0 & 2 & 1 & 1 & 1 & 1 & 2\end{array}$

$\begin{array}{llllllllllll}2 & 0 & 0 & 0 & 1 & 1 & 1 & 1 & 1 & 1 & 1 & 2\end{array}$

$\begin{array}{llllllllllll}2 & 0 & 0 & 0 & 1 & 1 & 2 & 1 & 1 & 1 & 1 & 2\end{array}$

$\begin{array}{llllllllllll}2 & 0 & 0 & 0 & 1 & 0 & 1 & 1 & 1 & 1 & 1 & 1\end{array}$

$\begin{array}{llllllllllll}2 & 0 & 0 & 0 & 1 & 0 & 1 & 1 & 1 & 1 & 2 & 1\end{array}$

$\begin{array}{llllllllllll}1 & 1 & 1 & 0 & 0 & 0 & - & - & 1 & 1 & 1 & 2\end{array}$

$\begin{array}{lllllllllllll}1 & 1 & 1 & 0 & 0 & 0 & - & - & 1 & 1 & 1 & 2\end{array}$

$\begin{array}{llllllllllll}1 & 1 & 1 & 0 & 0 & 0 & - & - & 1 & 1 & 2 & 2\end{array}$

$\begin{array}{llllllllllll}2 & 0 & 0 & 0 & 1 & 0 & 1 & 1 & 1 & 1 & 1 & 1\end{array}$

$\begin{array}{llllllllllll}2 & 0 & 0 & 0 & 1 & 0 & 1 & 1 & 1 & 1 & 2 & 2\end{array}$

$\begin{array}{lllllllllllll}1 & 1 & 1 & 0 & 0 & 0 & - & - & 1 & 1 & 2 & 2\end{array}$

$\begin{array}{llllllllllll}1 & 1 & 1 & 0 & 0 & 0 & - & - & 1 & 1 & 3 & 2\end{array}$

$\begin{array}{lllllllllllllllll}1 & 1 & 1 & 0 & 0 & 0 & - & - & 1 & 1 & 3 & 2\end{array}$

$\begin{array}{lllllllllllll}1 & 1 & 1 & 0 & 0 & 0 & - & - & 1 & 1 & 2 & 1\end{array}$

$\begin{array}{lllllllllllll}1 & 1 & 1 & 0 & 0 & 0 & - & - & 1 & 1 & 3 & 1\end{array}$

$\begin{array}{llllllllllll}1 & 1 & 1 & 0 & 0 & 0 & - & - & 1 & 1 & 3 & 1\end{array}$ 
Species

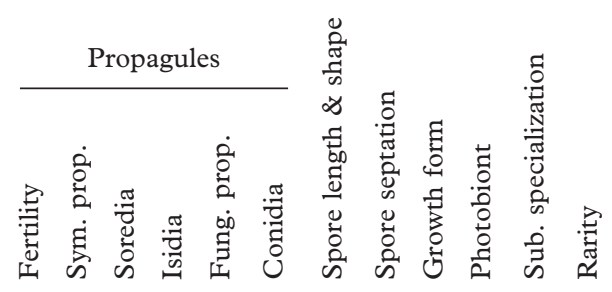

Leparia rigidula

Leprocaulon microscopicum

Leproloma membranaceum

L. vouauxii

Leptochidium albociliatum

Leptogium corniculatum

L. gelatinosum

L. intermedium

L. lichenoides

L. saturninum

L. subtile

L. tenuissimum

L. teretiusculum

Leptorhaphis epidermidis

Lobaria pulmonaria

Lobothallia radiosa

Loxospora cismonica

L. elatina

Megaspora verrucosa

Menegazzia terebrata

Micarea bauschiana

M. botryoides

M. cinerea

M. coppinsii

$M$. denigrata

M. erratica

M. lignaria

M. lithinella

M. melaena

$\begin{array}{llllllllllll}1 & 1 & 1 & 0 & 0 & 0 & - & - & 1 & 1 & 3 & 1 \\ 1 & 1 & 1 & 0 & 0 & 0 & - & - & 1 & 1 & 3 & 2 \\ 1 & 1 & 1 & 0 & 0 & 0 & - & - & 1 & 1 & 3 & 2 \\ 1 & 1 & 1 & 0 & 0 & 0 & - & - & 1 & 1 & 3 & 2 \\ 2 & 1 & 0 & 1 & 1 & 0 & 4 & 2 & 3 & 3 & 2 & 2 \\ 1 & 1 & 0 & 1 & 0 & 0 & 3 & 4 & 3 & 3 & 3 & 2 \\ 2 & 0 & 0 & 0 & 1 & 0 & 3 & 4 & 3 & 3 & 3 & 2 \\ 2 & 1 & 0 & 1 & 1 & 0 & 3 & 4 & 3 & 3 & 3 & 2 \\ 1 & 1 & 0 & 1 & 0 & 0 & - & - & 3 & 3 & 3 & 2 \\ 1 & 1 & 0 & 1 & 0 & 0 & - & - & 3 & 3 & 2 & 2 \\ 2 & 0 & 0 & 0 & 1 & 0 & 3 & 4 & 3 & 3 & 2 & 2 \\ 1 & 1 & 0 & 1 & 0 & 0 & - & - & 3 & 3 & 2 & 2 \\ 1 & 1 & 0 & 1 & 0 & 0 & - & - & 3 & 3 & 2 & 2 \\ 2 & 0 & 0 & 0 & 1 & 1 & 4 & 2 & 1 & 2 & 1 & 2 \\ 1 & 1 & 1 & 1 & 1 & 1 & - & - & 3 & 1 & 2 & 2 \\ 2 & 0 & 0 & 0 & 1 & 1 & 1 & 1 & 1 & 1 & 1 & 2 \\ 2 & 0 & 0 & 0 & 1 & 0 & 4 & 3 & 1 & 1 & 1 & 2 \\ 1 & 1 & 1 & 0 & 1 & 1 & - & - & 1 & 1 & 2 & 2 \\ 2 & 0 & 0 & 0 & 1 & 0 & 3 & 1 & 1 & 1 & 2 & 2 \\ 1 & 1 & 1 & 0 & 1 & 1 & - & - & 2 & 1 & 2 & 2 \\ 2 & 0 & 0 & 0 & 1 & 1 & 2 & 1 & 1 & 1 & 2 & 2 \\ 2 & 1 & 1 & 0 & 1 & 1 & 2 & 2 & 1 & 1 & 3 & 2 \\ 2 & 0 & 0 & 0 & 1 & 1 & 4 & 3 & 1 & 1 & 2 & 2 \\ 1 & 1 & 1 & 0 & 1 & 1 & - & - & 1 & 1 & 1 & 2 \\ 2 & 0 & 0 & 0 & 1 & 1 & 1 & 2 & 1 & 1 & 3 & 1 \\ 2 & 0 & 0 & 0 & 1 & 1 & 1 & 1 & 1 & 1 & 1 & 2 \\ 2 & 0 & 0 & 0 & 1 & 1 & 4 & 3 & 1 & 1 & 1 & 2 \\ 2 & 0 & 0 & 0 & 1 & 1 & 2 & 1 & 1 & 1 & 2 & 2 \\ 2 & 1 & 1 & 0 & 1 & 1 & 4 & 3 & 1 & 1 & 3 & 2\end{array}$

Species

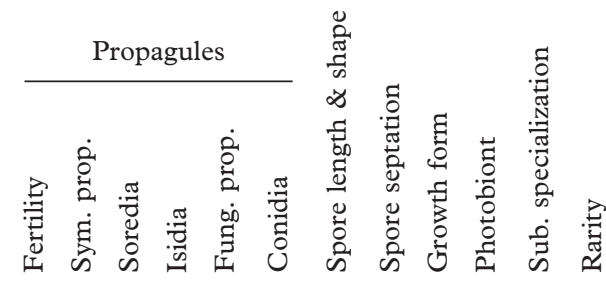

Micarea myriocarpa

M. nitschkeana

M. peliocarpa

M. prasina agg.

$M$. sylvicola

$M$. synotheoides

M. turfosa

Microcalicium arenarium

Miriquidica deusta

M. leucophaea

Mycobilimbia carneoalbida

M. epixanthoides

$M$. hypnorum

M. sabuletorum

$M$. sanguineoatra

Mycoblastus alpinus

M. caesius

M. fucatus

M. sanguinarius

Nephroma laevigatum

$N$. parile

Normandina pulchella

Ochrolechia alboflavescens

$O$. androgyna agg.

$O$. arborea

O. microstictoides

O. pallescens

O. parella

O. subviridis

\begin{tabular}{cccccccccccc}
2 & 1 & 1 & 0 & 1 & 1 & 2 & 2 & 1 & 1 & 2 & 2 \\
2 & 0 & 0 & 0 & 1 & 1 & 2 & 3 & 1 & 1 & 2 & 2 \\
2 & 0 & 0 & 0 & 1 & 1 & 4 & 3 & 1 & 1 & 3 & 2 \\
1 & 1 & 1 & 0 & 1 & 1 & - & - & 1 & 1 & 3 & 1 \\
2 & 0 & 0 & 0 & 1 & 1 & 1 & 1 & 1 & 1 & 2 & 2 \\
2 & 1 & 1 & 0 & 1 & 1 & 4 & 3 & 1 & 1 & 2 & 2 \\
2 & 0 & 0 & 0 & 1 & 1 & 4 & 2 & 1 & 1 & 1 & 2 \\
2 & 0 & 0 & 0 & 1 & 0 & 2 & 2 & 1 & - & 2 & 2 \\
2 & 0 & 0 & 0 & 1 & 0 & 1 & 1 & 1 & 1 & 1 & 2 \\
2 & 0 & 0 & 0 & 1 & 0 & 1 & 1 & 1 & 1 & 1 & 2 \\
2 & 0 & 0 & 0 & 1 & 0 & 4 & 3 & 1 & 1 & 2 & 2 \\
1 & 1 & 1 & 0 & 0 & 0 & - & - & 1 & 1 & 2 & 2 \\
2 & 0 & 0 & 0 & 1 & 0 & 1 & 3 & 1 & 1 & 3 & 2 \\
2 & 0 & 0 & 0 & 1 & 0 & 4 & 3 & 1 & 1 & 3 & 1 \\
2 & 0 & 0 & 0 & 1 & 0 & 2 & 3 & 1 & 1 & 2 & 2 \\
1 & 1 & 1 & 0 & 0 & 0 & - & - & 1 & 1 & 2 & 2 \\
1 & 1 & 1 & 0 & 0 & 0 & - & - & 1 & 1 & 2 & 2 \\
1 & 1 & 1 & 0 & 0 & 0 & - & - & 1 & 1 & 2 & 2 \\
2 & 1 & 1 & 0 & 1 & 0 & 3 & 1 & 1 & 1 & 3 & 2 \\
na & 1 & 0 & 1 & 1 & 1 & 4 & 3 & 3 & 3 & 1 & 2 \\
1 & 1 & 1 & 0 & 1 & 1 & - & - & 3 & 3 & 2 & 2 \\
1 & 1 & 1 & 0 & 0 & 0 & - & - & 1 & 1 & 2 & 2 \\
1 & 1 & 1 & 0 & 0 & 0 & - & - & 1 & 1 & 1 & 2 \\
1 & 1 & 1 & 0 & 0 & 0 & - & - & 1 & 1 & 2 & 2 \\
1 & 1 & 1 & 0 & 0 & 0 & - & - & 1 & 1 & 1 & 1 \\
1 & 1 & 1 & 0 & 0 & 0 & - & - & 1 & 1 & 1 & 2 \\
2 & 0 & 0 & 0 & 1 & 0 & 3 & 1 & 1 & 1 & 1 & 2 \\
2 & 0 & 0 & 0 & 1 & 0 & 3 & 1 & 1 & 1 & 1 & 2 \\
1 & 1 & 0 & 1 & 0 & 0 & - & - & 1 & 1 & 1 & 2 \\
\hline
\end{tabular}


Ochrolechia szatalaensis

O. tartarea

O. turneri

Omphalina umbellifera

Opegrapha atra

O. corticola

. fumosa

O. ochrocheila

O. rufescens

O. sorediifera

$O$. varia

$O$. viridis

O. vulgata

Ophioparma ventosa

Pachyphiale carneola

P. fagicola

Pannaria conoplea

P. ignobilis

P. mediterranea

P. pezizoides

P. rubiginosa

P. sampaiana

Parmelia acetabulum

P. borreri

P. caperata

P. centrifuga

P. conspersa

P. discordans

$P$. disjuncta

P. elegantula

P. exasperata

P. exasperatula

P. flaventior

P. glabra

P. glabratula

P. hypoleucina

$P$. laevigata

P. loxode

P. mougeotii

P. olivacea

P. omphalodes

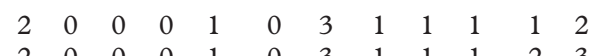
$\begin{array}{llllllllllll}2 & 0 & 0 & 0 & 1 & 0 & 3 & 1 & 1 & 1 & 2 & 3\end{array}$ $\begin{array}{llllllllllll}1 & 1 & 1 & 0 & 0 & 0 & - & - & 1 & 1 & 2 & 2\end{array}$ $\begin{array}{llllllllllll}1 & 0 & 0 & 0 & 0 & 0 & - & - & 1 & 1 & 2 & 2\end{array}$ $\begin{array}{llllllllllll}2 & 0 & 0 & 0 & 1 & 1 & 2 & 3 & 1 & 2 & 2 & 1\end{array}$ $\begin{array}{llllllllllll}1 & 1 & 1 & 0 & 0 & 0 & - & - & 1 & 2 & 1 & 3\end{array}$ $\begin{array}{llllllllllll}1 & 1 & 1 & 0 & 0 & 0 & - & - & 1 & 2 & 1 & 3\end{array}$ $\begin{array}{llllllllllll}2 & 0 & 0 & 0 & 1 & 1 & 4 & 3 & 1 & 2 & 2 & 2\end{array}$ $\begin{array}{llllllllllll}2 & 0 & 0 & 0 & 1 & 1 & 4 & 3 & 1 & 2 & 1 & 1\end{array}$ $\begin{array}{llllllllllll}1 & 1 & 1 & 0 & 1 & 1 & - & - & 1 & 2 & 1 & 2\end{array}$ $\begin{array}{llllllllllll}2 & 0 & 0 & 0 & 1 & 1 & 4 & 3 & 1 & 2 & 2 & 1\end{array}$ 200000 $2 \quad 00000$ $\begin{array}{llllllllllll}2 & 0 & 0 & 0 & 1 & 1 & 4 & 3 & 1 & 3 & 1 & 2\end{array}$ $\begin{array}{llllllllllll}2 & 0 & 0 & 0 & 1 & 1 & 4 & 3 & 1 & 2 & 1 & 2\end{array}$ $\begin{array}{llllllllllll}2 & 0 & 0 & 0 & 1 & 1 & 4 & 3 & 1 & 2 & 1 & 2\end{array}$ $\begin{array}{llllllllllll}1 & 1 & 1 & 0 & 0 & 0 & - & - & 2 & 3 & 2 & 2\end{array}$ $\begin{array}{llllllllllll}2 & 0 & 0 & 0 & 1 & 0 & 3 & 1 & 1 & 3 & 1 & 3\end{array}$ $\begin{array}{llllllllllll}1 & 1 & 1 & 0 & 0 & 0 & - & - & 1 & 3 & 1 & 3\end{array}$ $\begin{array}{llllllllllll}2 & 0 & 0 & 0 & 1 & 0 & 4 & 1 & 1 & 3 & 3 & 2\end{array}$ $\begin{array}{llllllllllll}2 & 0 & 0 & 0 & 1 & 0 & 3 & 1 & 1 & 3 & 2 & 3\end{array}$ $\begin{array}{llllllllllll}1 & 1 & 1 & 0 & 0 & 0 & - & - & 1 & 3 & 2 & 3\end{array}$ $\begin{array}{llllllllllll}\text { na } & 0 & 0 & 0 & 1 & 1 & - & - & 2 & 1 & 2 & 2\end{array}$ $\begin{array}{llllllllllll}1 & 1 & 1 & 0 & 1 & 1 & - & - & 2 & 1 & 2 & 2\end{array}$ $\begin{array}{llllllllllll}1 & 1 & 1 & 0 & 0 & 0 & - & - & 2 & 1 & 2 & 2\end{array}$

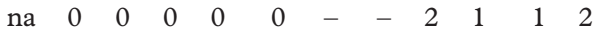
$\begin{array}{llllllllllll}\text { na } & 1 & 0 & 1 & 1 & 1 & - & - & 2 & 1 & 1 & 2\end{array}$ $\begin{array}{llllllllllll}1 & 0 & 0 & 0 & 1 & 1 & - & - & 2 & 1 & 2 & 2\end{array}$ $\begin{array}{llllllllllll}1 & 1 & 1 & 0 & 0 & 0 & - & - & 2 & 1 & 1 & 2\end{array}$ $\begin{array}{llllllllllll}1 & 1 & 0 & 1 & 0 & 0 & - & - & 2 & 1 & 1 & 2\end{array}$ $\begin{array}{llllllllllll}2 & 1 & 0 & 1 & 1 & 1 & 4 & 1 & 2 & 1 & 1 & 2\end{array}$ $\begin{array}{llllllllllll}1 & 1 & 0 & 1 & 0 & 0 & - & - & 2 & 1 & 2 & 1\end{array}$ $\begin{array}{llllllllllll}1 & 1 & 1 & 0 & 0 & 0 & - & - & 2 & 1 & \text { na } & 2\end{array}$ $\begin{array}{llllllllllll}2 & 0 & 0 & 0 & 1 & 0 & 1 & 1 & 2 & 1 & 2 & 2\end{array}$ $\begin{array}{llllllllllll}1 & 1 & 0 & 1 & 0 & 0 & - & - & 2 & 1 & 2 & 1\end{array}$ $\begin{array}{rrrrrrrrrrrr}1 & 1 & 1 & 0 & 0 & \text { na } & - & - & 3 & 1 & 1 & 3 \\ 1 & 1 & 1 & 0 & 1 & 1 & - & - & 3 & 1 & 3 & 2\end{array}$

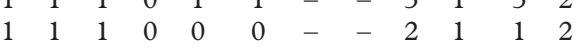
$\begin{array}{llllllllllll}1 & 1 & 1 & 0 & 1 & 1 & - & - & 2 & 1 & 1 & 2\end{array}$ $\begin{array}{llllllllllll}2 & 0 & 0 & 0 & 1 & 0 & 1 & 1 & 2 & 1 & 1 & 2\end{array}$
Parmelia panniformis P. pastillifera

P. pokornyi

$P$. protomatrae

P. pulla

P. quercina

P. reticulata

$P$. revoluta

P. saxatilis

P. somloensis

$P$. soredians

P. sorediosa

P. stygia

P. subargentifera

$P$. subaurifera

P. submontana

P. subrudecta

P. sulcata

P. taylorensis

P. tiliacea

P. tinctina

$P$. verruculifera

Parmeliella triptophylla

Parmeliopsis ambigua

P. hyperopta

Parmotrema chinense

P. crinitum

Peltigera aphthosa

P. canina

$P$. degenii

P. didactyla

P. elisabethae

$P$. horizontalis

P. hymenina

P. leucophlebia

P. membranacea

P. neckeri

P. polydactyla

P. praetextata

$P$. rufescens

Pertusaria albescens
0 na - -

$\begin{array}{llllllllll}0 & 0 & 0 & \text { na } & - & - & 2 & 1 & \text { na } & 2\end{array}$

$\begin{array}{llllllllllll}2 & 0 & 0 & 0 & 1 & 1 & 1 & 1 & 2 & 1 & 2 & 1\end{array}$

$\begin{array}{llllllllllll}2 & 0 & 0 & 0 & 1 & 1 & 1 & 1 & 2 & 1 & 1 & 2 \\ 1 & 1 & 1 & 0 & 1 & 1 & & & 3 & 1 & 2 & 2\end{array}$

$\begin{array}{llllllllllll}1 & 1 & 1 & 0 & 1 & 1 & - & - & 3 & 1 & 2 & 2\end{array}$

$\begin{array}{llllllllllll}1 & 1 & 1 & 0 & 0 & 0 & - & - & 2 & 1 & 2 & 2\end{array}$

$\begin{array}{llllllllllll}1 & 1 & 0 & 1 & 1 & 1 & - & - & 2 & 1 & 2 & 1\end{array}$

$\begin{array}{llllllllllll}2 & 0 & 0 & 0 & 1 & 0 & 1 & 1 & 2 & 1 & 2 & 2\end{array}$

$\begin{array}{llllllllllll}1 & 1 & 1 & 0 & 0 & 0 & - & - & 2 & 1 & 2 & 2\end{array}$

$\begin{array}{llllllllllll}1 & 1 & 1 & 0 & 0 & 0 & - & - & 2 & 1 & 1 & 2\end{array}$

$\begin{array}{llllllllllll}2 & 0 & 0 & 0 & 1 & 1 & 1 & 1 & 2 & 1 & 1 & 2\end{array}$

$\begin{array}{llllllllllll}1 & 1 & 1 & 0 & 0 & 0 & - & - & 3 & 1 & 1 & 1\end{array}$

$\begin{array}{llllllllllll}1 & 1 & 1 & 1 & 1 & 1 & - & - & 2 & 1 & 2 & 2\end{array}$

$\begin{array}{llllllllllll}1 & 1 & 1 & 1 & 0 & 0 & - & - & 3 & 1 & 1 & 2\end{array}$

$\begin{array}{llllllllllll}1 & 1 & 1 & 0 & 1 & 1 & - & - & 2 & 1 & 2 & 2\end{array}$

$\begin{array}{llllllllllll}1 & 1 & 1 & 0 & 1 & 1 & - & - & 2 & 1 & 2 & 1\end{array}$

$\begin{array}{llllllllllll}1 & 1 & 1 & 0 & 1 & 1 & - & - & 2 & 1 & 2 & 2\end{array}$

$\begin{array}{llllllllllll}1 & 1 & 0 & 1 & 1 & 1 & - & - & 2 & 1 & 2 & 1\end{array}$

$\begin{array}{llllllllllll}1 & 1 & 0 & 1 & 1 & 1 & - & - & 2 & 1 & 1 & 2\end{array}$

$\begin{array}{llllllllllll}1 & 1 & 1 & 0 & 0 & 0 & - & - & 2 & 1 & 1 & 2\end{array}$

$\begin{array}{llllllllllll}1 & 1 & 0 & 1 & 0 & 0 & - & - & 1 & 2 & 2 & 2\end{array}$

$\begin{array}{lllllllllllll}1 & 1 & 1 & 0 & 1 & 1 & - & - & 2 & 1 & 2 & 1\end{array}$

$\begin{array}{llllllllllll}1 & 1 & 1 & 0 & 1 & 1 & - & - & 2 & 1 & 2 & 2\end{array}$

$\begin{array}{llllllllllll}1 & 1 & 1 & 0 & 0 & 0 & - & - & 3 & 1 & 2 & 2\end{array}$

$\begin{array}{lllllllllllll}1 & 1 & 1 & 0 & 0 & 0 & - & - & 3 & 1 & 2 & 2\end{array}$

$\begin{array}{llllllllllll}1 & 0 & 0 & 0 & 0 & 0 & - & - & 3 & 1 & 3 & 2\end{array}$

$\begin{array}{llllllllllll}1 & 0 & 0 & 0 & 0 & 0 & - & - & 3 & 3 & 1 & 1\end{array}$

$\begin{array}{llllllllllll}1 & 1 & 0 & 1 & 0 & 0 & - & - & 3 & 3 & 3 & 2\end{array}$

$\begin{array}{llllllllllll}2 & 1 & 1 & 0 & 1 & 0 & 4 & 3 & 3 & 3 & 1 & 2\end{array}$

$\begin{array}{llllllllllll}2 & 0 & 0 & 0 & 1 & 0 & 4 & 3 & 3 & 3 & 2 & 2\end{array}$

$\begin{array}{llllllllllll}2 & 0 & 0 & 0 & 1 & 0 & 4 & 3 & 3 & 3 & 1 & 2\end{array}$

$\begin{array}{llllllllllll}2 & 0 & 0 & 0 & 1 & 0 & 4 & 3 & 3 & 3 & 3 & 2\end{array}$

$\begin{array}{lllllllllllll}1 & 0 & 0 & 0 & 0 & 0 & - & - & 3 & 1 & 2 & 2\end{array}$

$\begin{array}{llllllllllll}2 & 0 & 0 & 0 & 1 & 0 & - & - & 3 & 3 & 3 & 2\end{array}$

$\begin{array}{llllllllllll}2 & 0 & 0 & 0 & 1 & 0 & 4 & 3 & 3 & 3 & 2 & 2\end{array}$

$\begin{array}{llllllllllll}2 & 0 & 0 & 0 & 1 & 0 & 4 & 3 & 3 & 3 & 2 & 2\end{array}$

$\begin{array}{llllllllllll}2 & 1 & 0 & 1 & 1 & 0 & - & - & 3 & 3 & 3 & 1\end{array}$

$\begin{array}{llllllllllll}2 & 0 & 0 & 0 & 1 & 0 & - & - & 3 & 3 & 1 & 1\end{array}$

$\begin{array}{lllllllllllll}1 & 1 & 1 & 0 & 0 & 0 & - & - & 1 & 1 & 3 & 1\end{array}$ 
Species

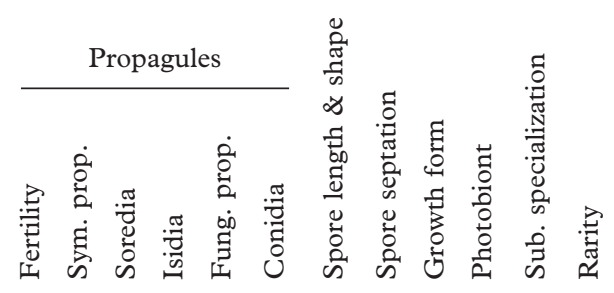

Species

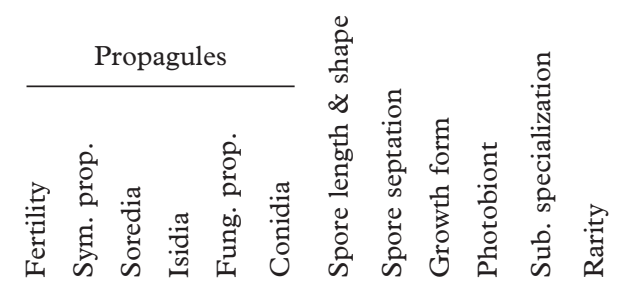

\begin{tabular}{|c|c|c|c|c|c|c|c|c|c|c|c|c|}
\hline Pertusaria amara & 1 & 1 & 1 & 0 & 0 & 0 & - & - & 1 & 1 & 2 & 1 \\
\hline P. amarescens & 1 & 1 & 1 & 0 & 0 & 0 & - & - & 1 & na & 1 & 3 \\
\hline$P$. aspergilla & 1 & 1 & 1 & 1 & 0 & 0 & - & - & 1 & 1 & na & 2 \\
\hline P. coccodes & 1 & 1 & 0 & 1 & 0 & 0 & - & - & 1 & 1 & 2 & 2 \\
\hline P. corallina & 1 & 1 & 0 & 1 & 0 & 0 & - & - & 1 & 1 & 2 & 2 \\
\hline P. coronata & 1 & 1 & 0 & 1 & 0 & 0 & - & - & 1 & 1 & 1 & 2 \\
\hline P. excludens & 1 & 1 & 1 & 0 & 0 & 0 & - & - & 1 & 1 & 1 & 2 \\
\hline P. ficorum & 2 & 0 & 0 & 0 & 1 & 0 & 3 & 1 & 1 & 1 & 1 & 3 \\
\hline P. flavida & 1 & 1 & 1 & 0 & 0 & 0 & - & - & 1 & 1 & 1 & 2 \\
\hline P. hemisphaerica & 1 & 1 & 1 & 0 & 0 & 0 & - & - & 1 & 1 & 1 & 2 \\
\hline P. heterochroa & 2 & 0 & 0 & 0 & 1 & 0 & 4 & 1 & 1 & 1 & 1 & 2 \\
\hline P. hymenea & 2 & 0 & 0 & 0 & 1 & 1 & 3 & 1 & 1 & 1 & 2 & 2 \\
\hline P. lactea & 1 & 1 & 1 & 0 & 1 & 1 & - & - & 1 & 1 & 1 & 2 \\
\hline P. leioplaca & 2 & 0 & 0 & 0 & 1 & 1 & 3 & 1 & 1 & 1 & 1 & 2 \\
\hline P. leucosora & na & 1 & 1 & 0 & 0 & 0 & na & na & 1 & 1 & 1 & 3 \\
\hline P. leucostoma & 2 & 1 & 1 & 0 & 1 & 0 & 3 & 1 & 1 & 1 & 1 & 3 \\
\hline P. multipuncta & 2 & 1 & 1 & 0 & 1 & 0 & 4 & 1 & 1 & 1 & 2 & 2 \\
\hline P. ophthalmiza & 2 & 1 & 1 & 0 & 1 & 0 & 3 & 1 & 1 & 1 & 2 & 2 \\
\hline P. pertusa & 2 & 0 & 0 & 0 & 1 & 1 & 4 & 1 & 1 & 1 & 2 & 2 \\
\hline P. pseudocorallina & 1 & 1 & 0 & 1 & 0 & 0 & - & - & 1 & 1 & 1 & 2 \\
\hline P. pupillaris & 1 & 1 & 1 & 0 & 0 & 0 & - & - & 1 & 1 & 1 & 2 \\
\hline P. pustulata & 2 & 0 & 0 & 0 & 1 & 0 & 4 & 1 & 1 & 1 & 1 & 2 \\
\hline Petractis clausa & 2 & 0 & 0 & 0 & 1 & 0 & 4 & 3 & 1 & 2 & 1 & 2 \\
\hline Phaeographis dendritica & 2 & 0 & 0 & 0 & 1 & 0 & 4 & 3 & 1 & 2 & 1 & 3 \\
\hline Phaeographis lyellii & 2 & 0 & 0 & 0 & 1 & 1 & 4 & 3 & 1 & 2 & 1 & 3 \\
\hline Phaeophyscia ciliata & 2 & 0 & 0 & 0 & 1 & 0 & 3 & 2 & 2 & 1 & 1 & 2 \\
\hline P. endophoenicea & 1 & 1 & 1 & 0 & 1 & 1 & - & - & 2 & 1 & 2 & 1 \\
\hline P. nigricans & 1 & 1 & 1 & 1 & 1 & 1 & - & - & 2 & 1 & 2 & 1 \\
\hline P. orbicularis & na & 1 & 1 & 0 & 1 & 1 & - & - & 2 & 1 & 2 & 1 \\
\hline
\end{tabular}

Phlyctis agelaea

$P$. argena

Phyllopsora rosei

Physcia adscendens

P. aipolia

P. caesia

P. dubia

P. semipinnata

P. stellaris

P. tenella

P. tribacia

P. tribacioides

Physconia distorta

$P$. enteroxantha

P. grisea

P. perisidiosa

P. subpulverulenta

$P$. venusta

Placopsis gelida s.1.

Placopyrenium buceckii

Placynthiella dasaea

P. icmalea

P. uliginosa

Placynthium nigrum

Platismatia glauca

Polyblastia albida

P. cruenta

P. cupularis

P. sepulta

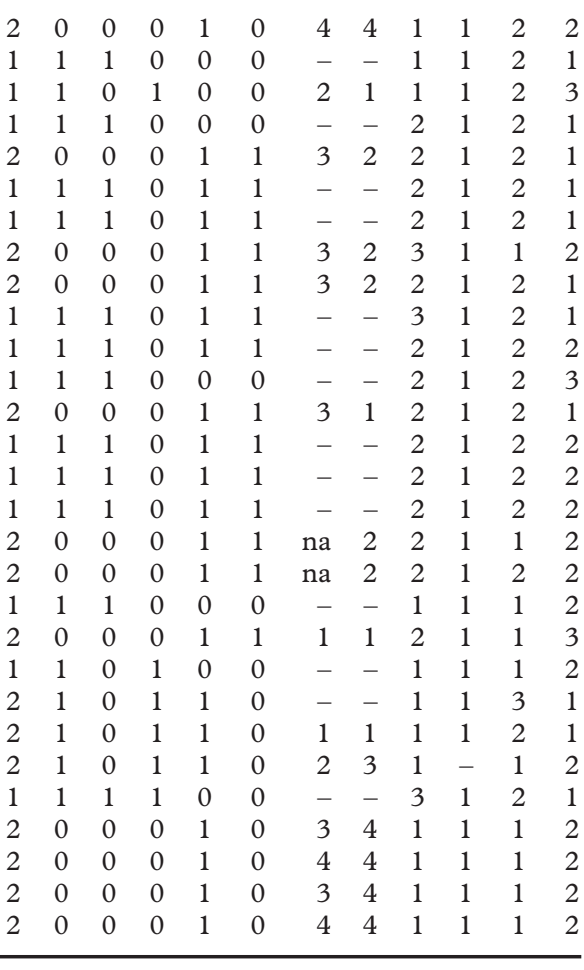

島 
Polyblastia theleodes

Polychidium muscicola

Polysporina lapponica

$P$. simplex

Porina aenea

P. chlorotica

P. guentheri

P. lectissima

P. leptalea

$P$. linearis

Porpidia albocaerulescens

$P$. cinereoatra

P. crustulata

P. macrocarpa

P. musiva

P. soredizodes

P. speirea

P. superba

P. tuberculosa

Protoblastenia incrustans

P. rupestris

Protoparmelia badia

P. hypotremella

Pseudevernia furfuracea

Psilolechia lucida

Pyrenula chlorospila

P. laevigata

P. macrospora

P. nitida

Pyrrhospora lusitanica

P. quernea

Racodium rupestre

Ramalina calicaris

R. canariensis

$R$. duriaei

$R$. farinacea

R. fastigiata

$R$. fraxinea

$R$. implectens

$R$. obtusata

R. pollinaria

$\begin{array}{llllllllllll}2 & 0 & 0 & 0 & 1 & 0 & 3 & 4 & 1 & 1 & 1 & 2 \\ 1 & 0 & 0 & 0 & 1 & 1 & - & - & 4 & 3 & 2 & 2 \\ 2 & 0 & 0 & 0 & 1 & 0 & 1 & 1 & 1 & 1 & 2 & 2 \\ 2 & 0 & 0 & 0 & 1 & 0 & 2 & 1 & 1 & 1 & 1 & 1 \\ 2 & 0 & 0 & 0 & 1 & 1 & 2 & 3 & 1 & 2 & 1 & 2 \\ 2 & 0 & 0 & 0 & 1 & 1 & 4 & 3 & 1 & 2 & 2 & 2 \\ 2 & 0 & 0 & 0 & 1 & 1 & 4 & 3 & 1 & 2 & 1 & 2 \\ 2 & 0 & 0 & 0 & 1 & 1 & 4 & 3 & 1 & 2 & 2 & 2 \\ 2 & 0 & 0 & 0 & 1 & 1 & 4 & 3 & 1 & 2 & 2 & 2 \\ 2 & 0 & 0 & 0 & 1 & 1 & 4 & 3 & 1 & 2 & 1 & 2 \\ 2 & 0 & 0 & 0 & 1 & 0 & 3 & 1 & 1 & 1 & 1 & 2 \\ 2 & 0 & 0 & 0 & 1 & 0 & 1 & 1 & 1 & 1 & 1 & 2 \\ 2 & 0 & 0 & 0 & 1 & 0 & 1 & 1 & 1 & 1 & 2 & 1 \\ 2 & 0 & 0 & 0 & 1 & 0 & 3 & 1 & 1 & 1 & 2 & 1 \\ 2 & 0 & 0 & 0 & 1 & 0 & 3 & 1 & 1 & 1 & 1 & 2 \\ 1 & 1 & 1 & 0 & 0 & 0 & - & - & 1 & 1 & 2 & 2 \\ 2 & 0 & 0 & 0 & 1 & 0 & 1 & 1 & 1 & 1 & 1 & 3 \\ 2 & 0 & 0 & 0 & 1 & 0 & 3 & 1 & 1 & 1 & 1 & 3 \\ 1 & 1 & 1 & 0 & 0 & 0 & - & - & 1 & 1 & 2 & 2 \\ 2 & 0 & 0 & 0 & 1 & 0 & 1 & 1 & 1 & 1 & 1 & 2 \\ 2 & 0 & 0 & 0 & 1 & 0 & 1 & 1 & 1 & 1 & 2 & 2 \\ 2 & 0 & 0 & 0 & 1 & 1 & 2 & 1 & 1 & 1 & 1 & 2 \\ 1 & 1 & 1 & 0 & 0 & 0 & - & - & 1 & 1 & 1 & 3 \\ 1 & 1 & 0 & 1 & 0 & 0 & - & - & 4 & 1 & 2 & 1 \\ 2 & 1 & 1 & 0 & 1 & 0 & 2 & 1 & 1 & 1 & 2 & 2 \\ 2 & 0 & 0 & 0 & 1 & 0 & 3 & 3 & 1 & 2 & 1 & 3 \\ 2 & 0 & 0 & 0 & 1 & 1 & 3 & 3 & 1 & 2 & 1 & 2 \\ 2 & 0 & 0 & 0 & 1 & 0 & 4 & 3 & 1 & 2 & 1 & 3 \\ 2 & 0 & 0 & 0 & 1 & 0 & 4 & 3 & 1 & 2 & 1 & 2 \\ 2 & 0 & 0 & 0 & 1 & 0 & 2 & 1 & 1 & 1 & 1 & 3 \\ 1 & 1 & 1 & 0 & 0 & 0 & - & - & 1 & 1 & 2 & 2 \\ 1 & 1 & 0 & 1 & 0 & 0 & - & - & 1 & 2 & 1 & 2 \\ 2 & 0 & 0 & 0 & 1 & 0 & 1 & 2 & 4 & 1 & 1 & 2 \\ 1 & 0 & 0 & 0 & 0 & 0 & - & - & 4 & 1 & 2 & 3 \\ 1 & 1 & 1 & 0 & 0 & 0 & - & - & 4 & 1 & 2 & 3 \\ 1 & 1 & 1 & 0 & 0 & 0 & - & - & 4 & 1 & 2 & 1 \\ 2 & 0 & 0 & 0 & 1 & 0 & 1 & 2 & 4 & 1 & 2 & 2 \\ 2 & 0 & 0 & 0 & 1 & 0 & 1 & 2 & 4 & 1 & 1 & 2 \\ 1 & 0 & 0 & 0 & 0 & 0 & - & - & 4 & 1 & 1 & 3 \\ 1 & 1 & 1 & 0 & 0 & 0 & - & - & 4 & 1 & 2 & 2 \\ 1 & 1 & 1 & 0 & 0 & 0 & - & - & 4 & 1 & 2 & 1\end{array}$

Ramalina pusilla

Ramonia interjecta

Reichlingia leopoldii

Rhizocarpon constrictum

$R$. eupetraeum

$R$. geminatum

R. geographicum

$R$. hochstetteri

R. lavatum

R. lecanorinum

$R$. macrosporum

R. obscuratum

$R$. oederi

$R$. petraeum

$R$. polycarpum

R. tetrasporum

R. umbilicatum

$R$. viridiatrum

Rimularia fusca

$R$. intercedens

Rinodina archaea

$R$. aspera

$R$. atrocinerea

R. bischoffii

$R$. capensis

$R$. colobina

$R$. confragosa

$R$. dubyana

$R$. efflorescens

$R$. exigua

$R$. gennarii

R. immersa

$R$. orculata

$R$. oxydata

$R$. polysporoides

$R$. pyrina

$R$. sophodes

R. sp. 1

$R$. subglaucescens

Ropalospora viridis

Ropalospora vinidis

$\begin{array}{rrrrrrrrrrrr}1 & 0 & 0 & 0 & 0 & 0 & - & - & 4 & 1 & 2 & 3 \\ 2 & 0 & 0 & 0 & 1 & 0 & 4 & \text { na } & 1 & 1 & 1 & 3 \\ 1 & 0 & 0 & 0 & 1 & 1 & - & - & 1 & 2 & 1 & 3 \\ 2 & 0 & 0 & 0 & 1 & 0 & 3 & 4 & 1 & 1 & 1 & 2 \\ 2 & 0 & 0 & 0 & 1 & 0 & 3 & 2 & 1 & 1 & 1 & 2 \\ 2 & 0 & 0 & 0 & 1 & 0 & 3 & 4 & 1 & 1 & 1 & 2 \\ 2 & 0 & 0 & 0 & 1 & 0 & 3 & 4 & 1 & 1 & 1 & 1 \\ 2 & 0 & 0 & 0 & 1 & 0 & 3 & 2 & 1 & 1 & 1 & 2 \\ 2 & 0 & 0 & 0 & 1 & 0 & 3 & 4 & 1 & 1 & 1 & 2 \\ 2 & 0 & 0 & 0 & 1 & 0 & 3 & 4 & 1 & 1 & 1 & 2 \\ 2 & 0 & 0 & 0 & 1 & 0 & 3 & 4 & 1 & 1 & 1 & 2 \\ 2 & 0 & 0 & 0 & 1 & 0 & 3 & 4 & 1 & 1 & 1 & 1 \\ 2 & 1 & 1 & 0 & 1 & 0 & 2 & 3 & 1 & 1 & 1 & 2 \\ 2 & 0 & 0 & 0 & 1 & 0 & 4 & 4 & 1 & 1 & 1 & 2 \\ 2 & 0 & 0 & 0 & 1 & 0 & 3 & 2 & 1 & 1 & 1 & 1 \\ 2 & 0 & 0 & 0 & 1 & 0 & 3 & 4 & 1 & 1 & 1 & 2 \\ 2 & 0 & 0 & 0 & 1 & 0 & 3 & 4 & 1 & 1 & 1 & 2 \\ 2 & 0 & 0 & 0 & 1 & 0 & 3 & 4 & 1 & 1 & 1 & 2 \\ \text { na } & \text { na } & \text { na } & \text { na } & 0 & 0 & - & - & 1 & 1 & \text { na } & 3 \\ 1 & 1 & 0 & 1 & 0 & 0 & - & - & 1 & 1 & 1 & 2 \\ 2 & 0 & 0 & 0 & 1 & 0 & 3 & 2 & 1 & 1 & 2 & 2 \\ 2 & 0 & 0 & 0 & 1 & 0 & 3 & 2 & 1 & 1 & 1 & 3 \\ 2 & 0 & 0 & 0 & 1 & 1 & 3 & 2 & 1 & 1 & 1 & 2 \\ 2 & 0 & 0 & 0 & 1 & 0 & 3 & 2 & 1 & 1 & 1 & 2 \\ 2 & 0 & 0 & 0 & 1 & 0 & 3 & 2 & 1 & 1 & 1 & 2 \\ 2 & 0 & 0 & 0 & 1 & 0 & 3 & 2 & 1 & 1 & 1 & 2 \\ 2 & 0 & 0 & 0 & 1 & 0 & 3 & 2 & 1 & 1 & 1 & 2 \\ 2 & 0 & 0 & 0 & 1 & 0 & 1 & 2 & 1 & 1 & 2 & 2 \\ 1 & 1 & 1 & 0 & 0 & 0 & - & - & 1 & 1 & 1 & 2 \\ 2 & 0 & 0 & 0 & 1 & 0 & 3 & 2 & 1 & 1 & 1 & 2 \\ 2 & 0 & 0 & 0 & 1 & 1 & 3 & 2 & 1 & 1 & 1 & 2 \\ 2 & 0 & 0 & 0 & 1 & 0 & 3 & 2 & 1 & 1 & 1 & 2 \\ 2 & 0 & 0 & 0 & 1 & 1 & 1 & 2 & 1 & 1 & 1 & 2 \\ 2 & 0 & 0 & 0 & 1 & 0 & 3 & 2 & 1 & 1 & 1 & 2 \\ 2 & 0 & 0 & 0 & 1 & 0 & 1 & 2 & 1 & 1 & 1 & 2 \\ 2 & 0 & 0 & 0 & 1 & 0 & 1 & 2 & 1 & 1 & 1 & 2 \\ 2 & 0 & 0 & 0 & 1 & 0 & 3 & 2 & 1 & 1 & 1 & 2 \\ 2 & 0 & 0 & 0 & 1 & 1 & 3 & 2 & 1 & 1 & 1 & \text { na } \\ 2 & 0 & 0 & 0 & 1 & 0 & 3 & 2 & 1 & 1 & 2 & 2 \\ 1 & 1 & 1 & 0 & 0 & 0 & - & - & 1 & 1 & 1 & 1 \\ 2 & 0 & 0 & 0 & 1 & 0 & 4 & 3 & 1 & 2 & 1 & 3 \\ & & & & & & & & & & & \end{array}$


Species

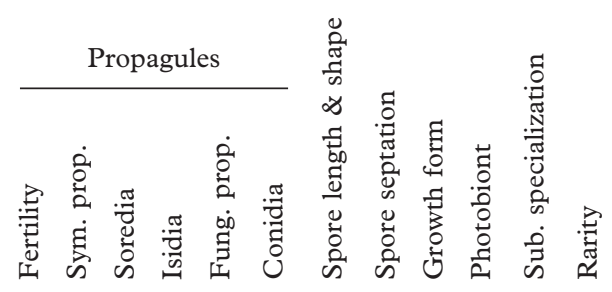

Sarcogyne regularis

Sarcosagium campestre

Schaereria cinereorufa

S. fuscocinerea

Schismatomma cretaceum

S. decolorans

S. pericleum

S. picconianum

Scoliosporum chlorococcum

S. gallurae

S. sarothamni

S. umbrinum

Sphaerophorus globosus

Staurothele frustulenta

S. guestphalica

S. rupifraga

Stereocaulon paschale

S. saxatile

Strangospora ochrophora

S. pinicola

Strigula stigmatella

S. taylorii

Tephromela atra

T. pertusarioides

Thelidium decipiens

T. minutulum

T. olivaceum

T. papulare

T. pyrenophorum

$\begin{array}{llllllllllll}2 & 0 & 0 & 0 & 1 & 0 & 1 & 1 & 1 & 1 & 2 & 2 \\ 2 & 0 & 0 & 0 & 1 & 0 & 2 & 1 & 1 & 1 & 3 & 2 \\ 2 & 0 & 0 & 0 & 1 & 1 & 1 & 1 & 1 & 1 & 2 & 2 \\ 2 & 0 & 0 & 0 & 1 & 1 & 2 & 1 & 1 & 1 & 1 & 2 \\ 1 & 1 & 1 & 0 & 0 & 0 & - & - & 1 & 2 & 1 & 3 \\ 1 & 1 & 1 & 0 & 0 & 0 & - & - & 1 & 2 & 1 & 2 \\ 1 & 1 & 1 & 0 & 0 & 0 & - & - & 1 & 2 & 2 & 2 \\ 2 & 0 & 0 & 0 & 1 & 0 & 4 & 3 & 1 & 2 & 1 & 2 \\ 2 & 1 & 1 & 0 & 1 & 0 & 4 & 3 & 1 & 1 & 1 & 1 \\ 2 & 1 & 1 & 0 & 1 & 0 & 4 & 3 & 1 & 1 & 1 & 2 \\ 2 & 1 & 1 & 0 & 1 & 0 & 4 & 3 & 1 & 1 & 1 & 1 \\ 2 & 1 & 1 & 0 & 1 & 0 & 4 & 3 & 1 & 1 & 2 & 1 \\ 1 & 0 & 0 & 0 & 0 & 0 & - & - & 1 & 1 & 3 & 2 \\ 2 & 0 & 0 & 0 & 1 & 0 & 3 & 4 & 1 & 1 & 1 & 2 \\ 2 & 0 & 0 & 0 & 1 & 0 & 4 & 4 & 1 & 1 & 1 & 2 \\ 2 & 0 & 0 & 0 & 1 & 0 & 3 & 4 & 1 & 1 & 1 & 2 \\ 1 & 1 & 0 & 1 & 0 & 0 & - & - & 4 & 1 & 2 & 2 \\ 1 & 1 & 0 & 1 & 0 & 0 & - & - & 1 & 1 & 2 & 2 \\ 2 & 0 & 0 & 0 & 1 & 1 & 1 & 1 & 1 & 1 & 2 & 2 \\ 2 & 0 & 0 & 0 & 1 & 1 & 1 & 1 & 1 & 1 & 2 & 2 \\ 2 & 0 & 0 & 0 & 1 & 1 & 4 & 3 & 1 & 2 & 2 & 2 \\ 2 & 0 & 0 & 0 & 1 & 1 & 4 & 2 & 1 & 2 & 1 & 2 \\ 2 & 0 & 0 & 0 & 1 & 1 & 1 & 1 & 1 & 1 & 2 & 2 \\ 1 & 1 & 1 & 0 & 0 & 0 & - & - & 1 & 1 & 1 & 2 \\ 2 & 0 & 0 & 0 & 1 & 0 & 3 & 2 & 1 & 1 & 1 & 2 \\ 2 & 0 & 0 & 0 & 1 & 0 & 3 & 2 & 1 & 1 & 2 & 2 \\ 2 & 0 & 0 & 0 & 1 & 0 & 3 & 2 & 1 & 1 & 1 & 2 \\ 2 & 0 & 0 & 0 & 1 & 0 & 4 & 3 & 1 & 1 & 1 & 2 \\ 2 & 0 & 0 & 0 & 1 & 0 & 4 & 2 & 1 & 1 & 1 & 2\end{array}$

Species

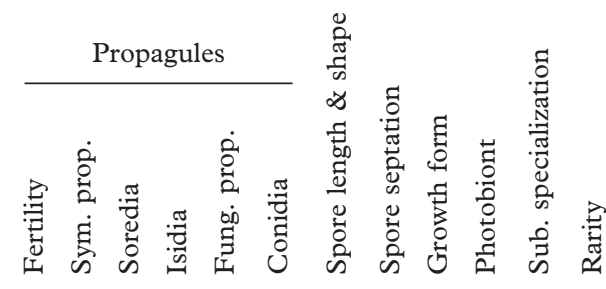

Thelocarpon laurer

Thelotrema lepadinum

Toninia sedifolia

T. taurica

Trapelia coarctata

T. corticola

T. involuta

T. mooreana

T. obtegens

$T$. placodioides

Trapeliopsis flexuosa

T. gelatinosa

1. granulosa

Tremolecia atrata

Tylothallia biformigera

Umbilicaria cylindrica

$U$. deusta

$U$. grisea

U. polyphylla

U. polyrrhiza

Usnea ceratina

U. cornuta

$U$. esperantiana

$U$. filipendula

$U$. fulvoreagens

U. glabrata

$U$. hirta

U. lapponica

$\begin{array}{rlllllllllll}2 & 0 & 0 & 0 & 1 & 0 & 1 & 1 & 1 & 1 & 2 & 2 \\ 2 & 0 & 0 & 0 & 1 & 0 & 4 & 4 & 1 & 2 & 1 & 2 \\ \text { na } & 0 & 0 & 0 & 0 & 0 & - & - & 1 & 1 & 2 & 2 \\ \text { na } & 0 & 0 & 0 & 0 & 0 & - & - & 2 & 1 & 1 & 2 \\ 2 & 0 & 0 & 0 & 1 & 0 & 3 & 1 & 1 & 1 & 2 & 1 \\ 1 & 1 & 1 & 0 & 0 & 0 & - & - & 1 & 1 & 2 & 2 \\ 2 & 0 & 0 & 0 & 1 & 0 & 3 & 1 & 1 & 1 & 2 & 1 \\ 2 & 0 & 0 & 0 & 1 & 1 & 3 & 1 & 1 & 1 & 2 & 2 \\ 1 & 1 & 1 & 0 & 0 & 0 & - & - & 1 & 1 & 2 & 1 \\ 1 & 1 & 1 & 0 & 0 & 0 & - & - & 1 & 1 & 1 & 1 \\ \text { na } & 1 & 1 & 0 & 0 & 0 & - & - & 1 & 1 & 2 & 1 \\ 2 & 1 & 1 & 0 & 1 & 0 & 1 & 1 & 1 & 1 & 1 & 2 \\ 2 & 1 & 1 & 0 & 1 & 0 & 1 & 1 & 1 & 1 & 1 & 2 \\ 1 & 1 & 1 & 0 & 0 & 0 & - & - & 1 & 1 & 2 & 2 \\ 2 & 0 & 0 & 0 & 1 & 1 & 1 & 1 & 1 & 1 & 1 & 1 \\ 2 & 0 & 0 & 0 & 1 & 0 & 2 & 2 & 1 & 1 & 1 & 3 \\ 2 & 0 & 0 & 0 & 1 & 0 & 1 & 1 & 3 & 1 & 1 & 2 \\ 1 & 1 & 0 & 1 & 0 & 0 & - & - & 3 & 1 & 1 & 2 \\ 1 & 1 & 1 & 0 & 0 & 0 & - & - & 3 & 1 & 1 & 2 \\ 1 & 0 & 0 & 0 & 1 & 1 & - & - & 3 & 1 & 1 & 2 \\ 1 & 0 & 0 & 0 & 1 & 1 & - & - & 3 & 1 & 1 & 2 \\ 1 & 1 & 1 & 1 & 0 & 0 & - & - & 5 & 1 & 1 & 2 \\ 1 & 1 & 1 & 1 & 0 & 0 & - & - & 5 & 1 & 2 & 3 \\ 1 & 1 & 1 & 1 & 0 & 0 & - & - & 5 & 1 & 1 & 3 \\ 1 & 1 & 0 & 1 & 0 & 0 & - & - & 5 & 1 & 2 & 2 \\ 1 & 1 & 1 & 0 & 0 & 0 & - & - & 5 & 1 & 1 & 2 \\ 1 & 1 & 1 & 1 & 0 & 0 & - & - & 5 & 1 & 1 & 2 \\ 1 & 1 & 0 & 1 & 0 & 0 & - & - & 5 & 1 & 2 & 2 \\ 1 & 1 & 1 & 0 & 0 & 0 & - & - & 5 & 1 & \text { na } & 2\end{array}$




\begin{tabular}{|c|c|c|c|c|c|c|c|c|c|c|c|}
\hline Usnea prostrata & 1 & 1 & 0 & 1 & 0 & 0 & - & - & 5 & 1 & na \\
\hline U. rigida & 2 & 0 & 0 & 0 & 1 & 0 & na & 1 & 5 & 1 & na \\
\hline U. rubicunda & 1 & 1 & 1 & 1 & 0 & 0 & - & - & 5 & 1 & 1 \\
\hline U. subfloridana & 1 & 1 & 0 & 1 & 0 & 0 & - & - & 5 & 1 & 1 \\
\hline U. wasmuthii & 1 & 1 & 1 & 1 & 0 & 0 & - & - & 5 & 1 & 1 \\
\hline Verrucaria amylacea & 2 & 0 & 0 & 0 & 1 & 0 & 3 & 1 & 1 & 1 & 1 \\
\hline$V$. aquatilis & 2 & 0 & 0 & 0 & 1 & 0 & 1 & 1 & 1 & 1 & 1 \\
\hline$V$. caerulea & 2 & 0 & 0 & 0 & 1 & 0 & 4 & 1 & 1 & 1 & 1 \\
\hline V. concinna & 2 & 0 & 0 & 0 & 1 & 0 & 3 & 1 & 1 & 1 & 1 \\
\hline$V$. dolosa & 2 & 0 & 0 & 0 & 1 & 0 & 2 & 1 & 1 & 1 & 1 \\
\hline$V$. dufourii & 2 & 0 & 0 & 0 & 1 & 0 & 3 & 1 & 1 & 1 & 1 \\
\hline$V$. foveolata & 2 & 0 & 0 & 0 & 1 & 0 & 3 & 1 & 1 & 1 & 1 \\
\hline V. fusconigrescens & 2 & 0 & 0 & 0 & 1 & 0 & 3 & 1 & 1 & 1 & 1 \\
\hline$V$. glaucina & 2 & 0 & 0 & 0 & 1 & 0 & 1 & 1 & 1 & 1 & 1 \\
\hline V. hochstetteri & 2 & 0 & 0 & 0 & 1 & 0 & 3 & 1 & 1 & 1 & 1 \\
\hline
\end{tabular}

Verrucaria lecideoides

V. macrostoma

$V$. maculiformis

$V$. muralis

$V$. nigrescens

V. viridula

Vulpicida pinastri

Xanthoria calcicola

$X$. candelaria agg.

$X$. elegans

$X$. parietina

$X$. polycarpa

$X y$ lographa vitiligo

Zamenhofia hibernica

\begin{tabular}{rrrrrrrrrrrr}
2 & 0 & 0 & 0 & 1 & 0 & 3 & 1 & 1 & 1 & 1 & 2 \\
2 & 0 & 0 & 0 & 1 & 0 & 3 & 1 & 1 & 1 & 1 & 1 \\
2 & 0 & 0 & 0 & 1 & 0 & 3 & 1 & 1 & 1 & 1 & 2 \\
2 & 0 & 0 & 0 & 1 & 0 & 3 & 1 & 1 & 1 & 1 & 1 \\
2 & 0 & 0 & 0 & 1 & 0 & 3 & 1 & 1 & 1 & 1 & 1 \\
2 & 0 & 0 & 0 & 1 & 0 & 3 & 1 & 1 & 1 & 1 & 2 \\
1 & 1 & 1 & 0 & 1 & 1 & - & - & 3 & 1 & 2 & 2 \\
2 & 1 & 0 & 1 & 1 & 1 & na & 2 & 3 & 1 & 2 & 1 \\
1 & 1 & 1 & 0 & 0 & 0 & - & - & 3 & 1 & 2 & 2 \\
2 & 0 & 0 & 0 & 1 & 0 & 1 & 2 & 2 & 1 & 1 & 1 \\
2 & 0 & 0 & 0 & 1 & 0 & 1 & 2 & 2 & 1 & 2 & 1 \\
2 & 0 & 0 & 0 & 1 & 0 & 1 & 2 & 3 & 1 & 2 & 1 \\
na & 1 & 1 & 0 & 1 & 1 & - & - & 1 & 1 & 1 & 2 \\
1 & 1 & 0 & 1 & 0 & 0 & - & - & 1 & 2 & 2 & 3 \\
\hline
\end{tabular}

$N$
웅

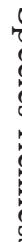

0
0
0
$?$
0
0
5
0
5
0
0
0
0
0
0
0
0
0
5
5
0
0
0
0
0
0
0
0
0
0
0
0
0
0
0
0 